\title{
Polarizing Effects of Early Exporting on Exit
}

DOI:

10.1007/s11575-016-0292-9

\section{Document Version}

Accepted author manuscript

Link to publication record in Manchester Research Explorer

\section{Citation for published version (APA):}

Deng, Z., Jean, R. J. B., \& Sinkovics, R. R. (2017). Polarizing Effects of Early Exporting on Exit. Management International Review, 57(2), 243-275. https://doi.org/10.1007/s11575-016-0292-9

\section{Published in:}

Management International Review

\section{Citing this paper}

Please note that where the full-text provided on Manchester Research Explorer is the Author Accepted Manuscript or Proof version this may differ from the final Published version. If citing, it is advised that you check and use the publisher's definitive version.

\section{General rights}

Copyright and moral rights for the publications made accessible in the Research Explorer are retained by the authors and/or other copyright owners and it is a condition of accessing publications that users recognise and abide by the legal requirements associated with these rights.

\section{Takedown policy}

If you believe that this document breaches copyright please refer to the University of Manchester's Takedown Procedures [http://man.ac.uk/04Y6Bo] or contact uml.scholarlycommunications@manchester.ac.uk providing relevant details, so we can investigate your claim.

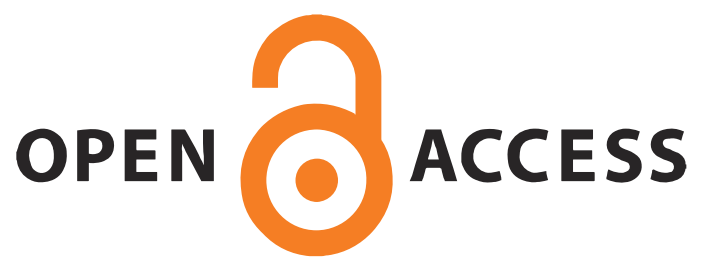


This is a pre-print / an Author's Accepted Manuscript (AAM) of an article published by Springer in Management International Review. Please cite the published article:

Deng, Ziliang, Ruey-Jer Bryan Jean, and Rudolf R. Sinkovics (2017), "Polarizing effects of early exporting on exit," Management International Review, 57 (2), 243-275.

https://doi.org/10.1007/s11575-016-0292-9

\author{
Ziliang Deng \\ School of Business, Renmin University of China, Beijing, China \\ dengziliang@rbs.org.cn \\ http://orcid.org/0000-0002-4767-2803 \\ Ruey-Jer 'Bryan' Jean \\ National Chengchi University, Taiwan \\ bryan@nccu.edu.tw \\ http://orcid.org/0000-0003-2461-7454 \\ Rudolf R. Sinkovics \\ The University of Manchester, Alliance Manchester Business School, UK \\ Rudolf.Sinkovics@manchester.ac.uk \\ https://www.research.manchester.ac.uk/portal/rudolf.sinkovics.html \\ http://orcid.org/0000-0002-4471-5054 \\ and \\ Lappeenranta University of Technology \\ Skinnarilankatu 34, PL 20, 53851 Lappeenranta, Finland
}




\title{
Polarizing Effects of Early Exporting on Exit
}

\author{
Ziliang Deng \\ School of Business, Renmin University of China, Beijing, China \\ Ruey-Jer "Bryan" Jean \\ Department of International Business, National Taiwan University, Taipei, Taiwan \\ Rudolf R. Sinkovics $(\bowtie)$ \\ The University of Manchester, Alliance Manchester Business School, Manchester, UK \\ and Lappeenranta University of Technology, Lappeenranta, Finland \\ Tel: +44(0)161-306-8980 \\ Rudolf.Sinkovics@manchester.ac.uk \\ www.manchester.ac.uk/research/rudolf.sinkovics
}

\begin{abstract}
Extant research offers limited and inconclusive findings on the effects of early exporting by new ventures. This longitudinal study examines such effects, taking into consideration the roles of competition and adaptation in international venturing and exiting. The findings alert us to the potentially negative impact of early exporting on exit. Despite the deterrent effect of exporter competition, those new ventures that engage in early international venturing are impelled to keep strategically alert and expedite their learning process, therefore prospering in the highly competitive environment. By attracting foreign investors, new ventures will be able to start exporting early, and endorsed by the knowledge advantages associated with foreign partners the rapid entrants have better continuation chances. At the same time, early exporting in a relatively less competitive environment or without foreign ownership will lead to higher exit likelihood. By highlighting the polarizing effects of early exporting in the life cycle of new ventures, this study reconciles the difference between the process model and theories on international entrepreneurship to some extent.
\end{abstract}

\section{Keywords}

Early exporting; competition; foreign ownership; exit

\section{Acknowledgements}

We appreciate comments from audience on earlier versions of this paper at AIB China Conference 2012, CIMaR 2013 Conference, AIB 2013 Annual Meeting, AIB 2014 Annual Meeting, Peking University and Renmin University of China. Deng is grateful for the support from National Natural Science Foundation of China (71202149; 71372157; 71232011). 


\title{
Polarizing Effects of Early Exporting on Exit
}

\begin{abstract}
Extant research offers limited and inconclusive findings on the effects of early exporting by new ventures. This longitudinal study examines such effects, taking into consideration the roles of competition and adaptation in international venturing and exiting. The findings alert us to the potentially negative impact of early exporting on exit. Despite the deterrent effect of exporter competition, those new ventures that engage in early international venturing are impelled to keep strategically alert and expedite their learning process, therefore prospering in the highly competitive environment. By attracting foreign investors, new ventures will be able to start exporting early, and endorsed by the knowledge advantages associated with foreign partners the rapid entrants have better continuation chances. At the same time, early exporting in a relatively less competitive environment or without foreign ownership will lead to higher exit likelihood. By highlighting the polarizing effects of early exporting in the life cycle of new ventures, this study reconciles the difference between the process model and theories on international entrepreneurship to some extent.
\end{abstract}

\section{Keywords}

Early exporting; competition; foreign ownership; exit 


\section{Introduction}

It is of significant strategic value to predict the duration of export projects based on their founding conditions, e.g. earliness of exporting (Geroski et al. 2010). However there has been no research explicitly examining the linkage between the timing of entry into export markets and subsequent exit. Extant studies so far have offered limited insights and inconclusive empirical findings on the effects of the foreign entry timing of new ventures on their post-entry dynamism (Autio et al. 2000; Hagen and Zucchella 2014). While the process model of internationalization suggests a sequential approach to foreign entry that helps firms to overcome the liabilities of foreignness (Johanson and Vahlne 1977), the literature on international entrepreneurship argues that early foreign entry helps firms to generate learning advantages of newness, which enables them to perform better in foreign markets (Autio et al. 2000; Gabrielsson et al. 2014).

Drawing on the perspective of organizational ecology, this study addresses the important but understudied link between early exporting and exit, in the case of startup exporters. We focus on exporting as it tends to be the most common foreign entry mode for startups, due to their limited resources for internationalization (Knight and Cavusgil 2004; Kuivalainen et al. 2007; Moen and Servais 2002). Exits from export markets have important strategic implications for startups as they are very likely to lead to firm closedown (Ilmakunnas and Nurmi 2010). Organizational ecology theory holds that the founding conditions of a firm or project will have a marked effect on its duration. The theory also holds that environmental selection and organizational adaptation are the main causes of organizational mortality (Hannan and Freeman 1989). In line with these theoretical propositions, we holistically examine the whole life cycle of young exporters, from birth to international venturing and exit, and we integrate with this, analyses on the antecedents and consequences of international entrepreneurship. We study how 
the earliness of exporting, as a founding condition of export projects, affects exiting from export projects, in our baseline model. Furthermore, we scrutinize the moderating effects of selection via exporter competition, and adaptation via foreign ownership, on the linkage between early exporting and exit from export projects.

To conduct the empirical analysis, this study employs a large longitudinal dataset of early exporters. We find that these exporters are likely to suffer if they choose a rapid entry strategy. The smallest and least inefficient new ventures tend to enter export markets most rapidly, although unfortunately they face a much higher risk of exit, manifesting the ecological selection process, which is amplified by the information asymmetry in the international entrepreneurship context. Moreover, competition between fellow exporters from the same country of origin and industry has a strong deterrent effect for potential entrants. However, once they get ready and enter international markets early, the exporter competition will have strong enabling and catalyzing effects on the learning capabilities and strategic vigilance of early exporters. Moreover, hosting foreign ownership helps exporters to improve their internal routines, access greater international networks and gain external legitimacy. Therefore, rapid entry into export markets with the presence of strong competition or foreign ownership will effectively reduce the likelihood of exit. At the same time, our empirical results indicate that early exporting in a relatively less competitive environment or without foreign ownership will lead to higher exit likelihood. By highlighting the polarizing effect of early exporting in the life cycle of new ventures, this study underscores the contingency conditions under which early entry into export markets may be either a wise or an inappropriate exporting strategy for a startup. 


\section{Theoretical background}

\subsection{Timing of internationalization and firm performance}

The timing of starting to conduct international business, or age at entry into international markets, is one of the most important defining features in international entrepreneurship (Autio et al. 2000; Sapienza et al. 2006). In the recently emerging stream of literature regarding the speed of internationalization, various dimensions of speed have been examined, such as the timing of entry (Autio et al. 2000), post-entry expansion speed in terms of scope of countries (McNaughton 2003), intensity of overseas sales in the sales portfolio, and degree of geographical proximity (Sui and Baum 2014). While the literature usually refers to those dimensions of speed interchangeably, early entry and rapid post-entry expansion are conceptually different and may involve distinctive degrees of risk and strategic commitment (Autio et al. 2000, pp. 909-910). Compared with firms preparing for post-entry expansion, candidates for early initial entry may have no prior international exposure or experience, encounter a much higher degree of information asymmetry, and incur a stronger liability of foreignness. Therefore, post-entry expansion strategies are bound to be more rational, better reflecting firms' internal resources and external environments (Mudambi and Zahra 2007).

There are different views regarding how early a firm should engage in international business. The process model holds that internationalization is an evolutionary process (Johanson and Vahlne 1977). Due to limited resources and knowledge reservoirs regarding overseas markets, as outsiders, firms at the early stages of internationalization usually cannot handle external challenges adequately (Johanson and Vahlne 2009; Liesch et al. 2011). The theory on international entrepreneurship argues that firms may enter international markets in their early stage of business (Glaister et al. 2014; Nummela et al. 2014). By relying on modern information 
technology, for example (Sinkovics et al. 2013; Yamin and Sinkovics 2006), early foreign entry may offer firms the "learning advantage of newness" that facilitates firm growth (Autio et al. 2000; Hagen and Zucchella 2014). Early internationalizers may exhibit particular traits that are ingrained in their organizational cultures, such as innovativeness, learning, dynamic capabilities and risk taking, which help them to accumulate market knowledge quickly and reduce international risks (Gabrielsson et al. 2014; Vahlne and Johanson 2013).

While the two aforementioned theories imply diverging effects of the timing of internationalization, the empirical evidence offers mixed results. For example, Mudambi and Zahra (2007) find that early internationalization does not result in a greater survival rate than sequential entry. They attribute the different survival rates of firms to firm resources and industrial environments. Carr et al. (2010) find that, while entry speed has a positive effect on post-entry short-term growth, the impact of speed on post-entry survival is inconclusive. Khavul et al. (2010) do not find a significant relationship between the timing of internationalization and firm growth either. Efrat and Shoham (2012) adopt a temporal approach and find that target market conditions have a short-run impact on firm performance, while firm capabilities exert long-lasting effects on firm success. However, neither the process model nor theories on international entrepreneurship fully explore the implications of early entry for exit. Exit from international markets, "de-internationalization", or the discontinuation of international business refers to the voluntary or forced reduction of international activities (Crick 2004; Welch and Welch 2009). Exit from international markets may be driven by a variety of factors, including changing market conditions, product life cycles, and low managerial commitment to international markets, among others (Benito and Welch 1997; Crick 2004). 


\subsection{Organizational ecology theory}

Organizational ecology theory explains the birth, growth and mortality of firms as a result of the combination of two general processes, namely selection and adaptation (Hannan and Freeman 1977). Selection is a result of competition for limited market "carrying capacity", such as quality labor, raw materials and customer resources, between firms that belong to a particular population, competition that will lead to the shutting down of inefficient firms and the growth of productive ones (Hannan and Freeman 1989; Nickel and Fuentes 2004). Firms can accommodate and defuse this selective challenge through adaptive activities, however. A firm may tailor its products to its target customers, learn how to deal with adverse market shocks, and gain isomorphic adaptation capabilities, which in turn enhances its life chances by addressing the problem of maintaining the flow of resources from the environment (Andries and Debackere 2007). Organizational ecology theory holistically examines a full spectrum of the life cycle. In particular, it focuses on the most essential features of firms, such as founding conditions, organizational routines and inertia that have marked effects on firm mortality. Therefore, it has proven to be particularly suitable for investigating small, entrepreneurial and transparent startups, rather than large, old and complex enterprises (Hannan and Freeman 1989, p.334). This theory has been adopted in entrepreneurship research to examine the effects of selection, adaptation and organizational imprinting on firms' birth and survival rates (Burke and van Stel 2014; Sapienza et al. 2006).

The insights generated about a domestic population of organizations may be extended to explain and forecast the dynamics in international markets (Javalgi et al. 2005). The rapid globalization of industrial ecosystems means that a firm is no longer confined within its own national boundary, making it imperative to examine the global context of a firm doing crossborder business (Rosenzweig and Singh 1991). International markets indeed provide a unique 
setting for exploring the special impact that organizational ecology may exert on the dynamic development of firms, particularly new ventures. An international market is rather different from a home market in that the former involves much more uncertainty in terms of customer preferences, exchange rates, distribution channels and transportation (Isenberg 2008). All these ecological conditions will impose upon firms a liability of foreignness and result in higher mortality risks (Lamin and Livanis 2013). From the perspective of organizational ecology, nascent ventures are particularly unsuitable for international business due to their lack of legitimacy in foreign markets as well as their shortage of market experience and financial resources, i.e. the liability of newness (Wiklund et al. 2010). Meanwhile, some new ventures are still tempted to enter overseas markets at a relatively early stage of their business operations, especially because overseas markets offer the promise of quickly opening up a new niche, achieving economies of scale and enhancing the learning effects for young ventures (Gabrielsson et al. 2014; Oviatt and McDougall 1994). Moreover, new ventures with insufficient scale and low efficiency may face strong competition from local rivals and therefore may endeavor to explore overseas markets opportunistically instead (Sui and Baum 2014). Will these firms be able to sustain their business in international markets, though? So far, the effects on postinternationalization exit, of ecological mechanisms such as market selection and firm adaptation, are greatly understudied.

The employment of organizational ecology theory will add significant value to this research. This study will examine how the founding conditions, i.e. the earliness of starting exporting projects, affect the duration of such projects. Specifically, we will scrutinize the roles of business routine construction, together with the triple liability of rapidness, newness and foreignness, which are associated with early exporting. Furthermore, we will investigate how the 
mechanisms in organizational ecology, namely market selection and firm adaptation, moderate the relationship between early exporting and exit. Moreover, this research is the first in the literature on international entrepreneurship to apply the life-cycle perspective of organizational ecology and to provide a full scanning of both the antecedents and consequences of early exporting behavior.

\section{Hypothesis development}

\subsection{Influence of the speed of entry into export markets on exit}

We focus on exit from export markets as the form of discontinuing internationalization. There exist several possible factors leading to export exit. First an exporter has successfully implemented its export strategies and is no longer interested in exporting, i.e. becoming a “disinterested" exporter (Crick 2004). Such a firm may strategically withdraw from the export market and explore their home market opportunities, or switch to more advanced modes of internationalization such as foreign direct investment (FDI). Second an exporter may find the opportunities in overseas markets shrinking, therefore returns to their home markets to remain functional i.e. becoming a "disappointed" exporters (Crick 2004; Liesch et al. 2011). Third the negative shocks in international markets are so unbearable that the exporters have to withdraw from international venturing, and completely cease the entire business operations (Welch and Welch 2009). To make the argument and subsequent empirical tests more scientific and accurate, we will purely focus on exit rather than firm bankruptcy as the consequence of early exporting.

The timing of international market entry is of great significance for the strategic behavior of new ventures (Jones and Coviello 2005; Oviatt and McDougall 1994) and there are potential benefits from a rapid entry into international markets. By entering international markets,

domestic new ventures transform themselves into members of a different population of 
organizations, i.e. startup exporters. Their traits in the founding year and the early exporting will have a marked effect on their post-entry dynamic development (Autio et al. 2000). Early exporting may speed up the process of knowledge learning and accumulation, and help young players in the international arena better understand the needs of their global customers and fulfill their global engagement, and build up their new products and manufacturing capabilities more quickly than their rivals. Therefore, early exporting may reduce the likelihood of subsequent exit.

On the other hand, rapid entry poses numerous challenges to the continuation of exporters (Sapienza et al. 2006). First and foremost, the aforementioned learning effect may not materialize automatically due to the liability of rapidness (Gabrielsson et al. 2014). As tremendous differences exist between home and export markets, firms need sufficient time to obtain market feedback from overseas customers, analyze customer needs and formulate new strategies to deal with new opportunities and challenges (Vermeulen and Barkema 2002).

Rapid entrants to exporting face constraints in terms of resources, experience, relationships, identity and legitimacy, i.e. the liability of newness (Nummela et al. 2014; Sapienza et al. 2006; Wiklund et al. 2010). Startup exporters face the dual task of constructing internal routines and external networks for the domestic environment, and at the same time developing different prototypes and international connections. This process requires ambidextrous learning and unlearning capabilities, which is a rather challenging ask for startup firms lacking experience (Puig et al. 2014). The domestic and international commitments will inevitably cause conflicts, which will overstretch the resources and capabilities of these startups (Benito and Welch 1997). Early exporters usually do not have enough capacity to handle such stressful tasks and will have to exit from exporting to simplify their business portfolio (Crick 2004; Sapienza et al. 2006). Even when startups rapidly enter an international market with 
abundant business opportunities, effective opportunity recognition is always associated with prior foreign experience and market knowledge (Hagen and Zucchella 2014; Nummela et al. 2014; Shane 2000).

Moreover, cross-border activities incur the liability of foreignness, i.e. additional negative shocks including unexpected exchange rate fluctuations and low foreign brand recognition, any of which could induce a liquidity problem for exporters. The lack of international business experience and good understanding of institutional distances requires tremendous time and effort to overcome (Eriksson et al. 1997). The triple liability of rapidness, newness and foreignness will substantially increase the likelihood of rapid-entry exporters exiting export markets. Therefore,

Hypothesis 1: The speed of entry into export markets is positively related to the probability of exit from export markets.

\subsection{Moderating effect of market selection with exporter competition}

The relationship between early entry and exit may be contingent on the degree of competition among fellow exporters from the home country and industry. Industrial competition has a close relationship with the exit of firms in general, and new ventures in particular, according to the organizational ecology theory (Geroski et al. 2010; Hannan and Freeman 1989; Mudambi and Zahra 2007). Once nascent firms enter export markets, they will face two types of export competitors in a host market, namely exporters from the home country and those from other countries. Exporters from the home country will generally be regarded by importers as a cohort of firms with relatively similar competitive advantages (Porter 1990). Such resource similarity and market commonality categorize exporters from each country and industry into separate strategic groups or population niches (Hannan and Freeman 1989). This is particularly the case for new-venture exporters, considering their general lack of prestigious brands and customer 
loyalty. As it is important to examine the population ecology of organizations in similar settings (Hannan and Freeman 1977; Javalgi et al. 2005), in the current study we confine "exporter competition" to the competition among exporters from the same country of origin and industry.

Exporter competition mitigates the relationship between early entry and exit. Undoubtedly competitive forces always squeeze the room of firms to grow and prosper (Porter 1980). But for the special cohort of internationally oriented and entrepreneurial exporters that tend to be innovative, proactive and risk-taking (McDougall and Oviatt 2000), the squeezing effects could be outweighed by the enabling effects manifested by equal market opportunities, organizational learning, and early construction of internationally oriented organizational routines. Competition and industrial concentration are two sides of the same coin. An industry is competitive when a considerable number of players are active in the market and the monopolistic power of each extant player is evenly distributed. The niche width for every exporter will be relatively equal in that case. Under such circumstances, the rapid entry of new ventures into a more competitive in nature (i.e. less concentrated and monopolized) export market instantly opens a window of opportunity in a new population niche and will substantially reduce the risks of exit from the export market. Moreover, behind the market competition are sometimes prosperous market opportunities that enable firms to be successful with early exporting. Rapid entry may offer quick access to these opportunities and better prosperity in the global market (Sleuwaegen and Onkelinx 2014). Particularly in emerging product lines such as mobile computing products, the market opportunities can be globally distributed (Mishkin and Clover 2014). Hence, the niche width is geographically large, although niches may easily become obsolete. Thus, rapid entry into such competitive markets will help young exporters to take the opportunity to secure certain overseas market niches sooner (McAran 2009). 
The competitive environment may also activate young exporters to fully unleash their potential of learning from their rival exporters from the same home country (Delios et al. 2007), given their market commonality and resource similarity (Chen 1996). Organizational learning depends on how firms assimilate knowledge when they encounter it (Autio et al. 2000). Under strong competition, early-entrant exporters may be stimulated to learn quickly from incumbent exporters and other fellow exporters in selecting the most promising destination markets, some of which will have relatively high exporter density and yet high legitimacy for new entrants. In a competitive market, rapidly exporting new ventures may have to quickly recruit talent from their incumbent rivals and harvest the international expertise spillover embodied in labor turnover. With rich business, institutional and exporting knowledge accumulated in their previous companies, such talent may efficiently educate newcomer exporters so that they lower their operational costs and risks in international markets (Eriksson et al. 1997).

In the face of strong competition, firms make the strategic choice of early exporting in synchronization with the construction of important organizational routines, administrative structures and strategic decision making (Delios et al. 2007; Sapienza et al. 2006). Such resources and capabilities, prepared for relatively competitive environments in the early stages of joining the organizational ecology of young exporters, will have a marked effect on post-entry exit (Hannan and Freeman 1989). In the face of a competitive environment, aggressive strategies may help strengthen the exit odds (Almor et al. 2014). The earlier a firm starts international venturing, the weaker the inertial resistance will be. Such firms will also be driven to develop new products, achieve cost efficiencies and try novel ways of attracting customers. All these routines tailored for the international market will be better synergized and more compatible with those developed for their domestic environment. The early construction of such organizational routines will 
become important internal sources of advantage, with which nascent exporters may readily and effectively handle subsequent market competition. Therefore, early exposure to exporter competition may effectively immunize new ventures by keeping them strategically alert and vigilantly guarding them from negative shocks, thereby generating "antibodies" that provide longer protection (Burke and Hussel 2013).

Hypothesis 2: Exporter competition negatively moderates the impact of entry speed on the probability of exit.

\subsection{Moderating effect of adaptation with foreign ownership}

The relationship between early entry and exit may also be dependent on the extent to which exporters adapt themselves to the international markets. If a startup firm plans to expand its business into an overseas country where it has no prior network connections, it will face strong liabilities of outsidership as well as foreignness (Johanson and Vahlne 2009). Due to bounded rationality and limited access to international network information, the independent market research of young exporters may not be able to identify as many opportunities as foreign insiders can (Johanson and Vahlne 2009; Shane 2000). Among a variety of measures that could be used to alleviate the liabilities of startup exporters, such as non-equity forms of partnership or networks (Uberbacher 2014), what brings immediate help is to attract foreign investment so as to leverage the international network advantage of the foreign investors in starting up the export business (Keil 2004).

From a resource perspective, foreign investors may provide domestic firms with access to the resources that are imperative for restructuring and developing international activities. Multinational enterprises (MNEs) are the most influential players in the contemporary global trade system. They coordinate global value chains, within their powerful networks of subsidiaries, 
contractual partners and arm's-length suppliers, which account for approximately $80 \%$ of global trade (UNCTAD 2013). Therefore, network position building is a vital condition for the postentry success of exporters in foreign markets. Foreign-invested early-entrant exporters may face lower exit hazards as they are embedded in the global value chain and the investing MNEs may offer effective quality assurance and widespread distribution channels for these ventures' products. The involvement of foreign investors will help optimize the organizational form and internal routines of exporters, such as providing staff training so that the firm can become a qualified supplier to the MNE's global production and sales networks (Javorcik 2004). Hosting investment from foreign companies can thus help rapid-entrant exporters to overcome their intrinsic reputational deficiencies in the international market, as a new "structural context" (Uberbacher 2014).

Strategic perspectives highlight the importance of gaining legitimacy among external stakeholders and resource providers such as customers, competitors and suppliers to counteract the effect of the liability of newness on a new venture's chances of business continuation (Uberbacher 2014). Within the broad population ecology in an overseas market, MNEs and startup exporters are the two extremes of the wide spectrum of market legitimacy, with the former possessing strong legitimacy after years of international business and the latter holding virtually no market visibility. Building shareholding partnerships with foreign investors, particularly MNEs at the top of the pyramid of ecology, helps rapid-entrant exporters to overcome their branding disadvantage and achieve isomorphism in these often rather disparate markets (Zhan and Luo 2008). Building international shareholding partnerships with branded MNEs will be seen as a signal that a startup exporter has a sound management system and highquality products (Brouthers et al. 2013). Endorsed by the branding effects of successful foreign 
investors, new ventures that rapidly start export businesses will quickly be exposed to a much wider spectrum of market opportunities. Therefore, they can readily leverage the "legitimacy spillover" (Li et al. 2007) from their foreign investors and more rapidly become accepted in host markets, harvesting a reputation premium and financial returns, and reducing their probability of exiting the export market.

A foreign investor may also provide a learning platform by leveraging its widespread international network and gathering market information in destination markets (Isenberg 2008). Foreign investors may educate indigenous new ventures with general information on how to make products that are more likely to be embraced by overseas customers and how to circumvent the typical pitfalls of international business (Keil 2004). When new ventures rapidly march into export markets, their foreign investors will help them gather market feedback, assimilate it and formulate adaptation strategies, producing swift and effective learning-by-doing effects if their foreign investors are experienced professionals in this field (Nordman and Melén 2008; Zahra et al. 2000). This learning through foreign ownership is vital for startups, as they are so new that they usually lack strong capabilities for performing market analysis as well as the "gene" (Hannan and Freeman 1977) of market-oriented decision making (Nummela et al. 2014). More importantly, the diseconomies of time compression encountered during rapid internationalization pose a significant challenge to profitability in foreign markets (Vermeulen and Barkema 2002). Building shareholding partnerships with foreign firms will improve the "genes" of domestic firms and help them more fully leverage the learning opportunities brought about by rapid entry, amplifying their learning advantage of newness (Autio et al. 2000). By rapidly entering foreign markets and learning from those markets with the aid of foreign investors, new-venture exporters will stay longer than their counterparts that also export early but without foreign investors. 
Hypothesis 3: Foreign ownership negatively moderates the impact of entry speed on the probability of exit.

A summary of our conceptual framework is illustrated in Figure 1.

\section{INTERT FIGURE 1 ABOUT HERE}

\section{Sample and methods}

\subsection{Sample}

The dataset used in this study is obtained from the National Bureau of Statistics (NBS) of China that conducted annual surveys of manufacturing enterprises during 1998-2008 that covered approximately $90 \%$ of the national manufacturing output each year. In 1998, NBS began to systematically collect data on private firms as mass privatization boomed (Chang and $\mathrm{Xu}$ 2008). We chose China as our research setting because Chinese exports have contributed a major share of the world's exports, making the ecology among Chinese exporters pertinent. For example, according to the United Nations commodity trade database (http://comtrade.un.org/), knitted fabrics made in China accounted for $31 \%$ and $46 \%$ of the global knitted fabrics imported by the European Union and the United States, respectively, in 2013. The dataset includes 2,638,016 observations of firms from all 30 two-digit sectors and covers all 31 provinces, autonomous regions and municipalities in China. We exclude all firms with more than 250 employees (595,674 observations), to make the results of our empirical study comparable with those obtained from extant studies of business venturing. Moreover, we exclude all firms that were founded before the first year of our sample, 1998 (936,211 observations). In doing so, we can calculate the number of years that elapsed before a firm started exporting. We also eliminate 
firms with more than $50 \%$ of their shares in foreign ownership to alleviate the impact of foreign headquarters and to maintain the entrepreneurial nature of the indigenous startup firms in the sample (176,956 observations). We drop all state-owned enterprises (22,549 observations), too. We define an "exit" as exporters completely stopping exporting to all destinations in the year $t$ after conducting exporting in the year $t-1$ (Puig et al. 2014; Sui and Baum 2014). The survey reports only the total export values of firms, which makes it impossible for us to further pin down a finer scenario of partial exit, i.e. exporters exiting from some export destinations yet remaining in others. We deleted firms that never export during the entire sample period $(742,592$ observations). Then, we removed exporters that started exporting after six years of their inception (67,466 observations.) to make sure that all exporters are startups and that their "elements of entrepreneurship" are well preserved (Jones et al. 2011). Following a routine in survival analysis (Cleves et al. 2004), we extended every firm's final observation by one year in order to generate a dummy variable "event" and to inform the Cox model whether the firm is still active in the year after the final observation. For example an INV exports during 2002-2005, thus in the extended data line it will be regarded as exiting from international markets in 2006. We obtained 145,284 observations with this data extension. After excluding 11,658 observations without values of main explanatory variables, we are left with 133,626 observations. Please refer to Appendix 1 for the sample screening process.

\subsection{Empirical model}

The primary objective of the empirical test is to examine the relationship between early entry into and exit from the export market. The test is implemented in two steps to remove the potential endogeneity problem related to entry speed. The strategic choices of a firm, such as the timing of their entry into the export market, are determined by both firm resources and surrounding 
industrial conditions (Mudambi and Zahra 2007). As we plan to test the "pure" effect of entry speed on exit, we need to control for such endogeneity involved in the strategic decision regarding how soon to start exporting. More importantly, as discussed previously in relation to the research framework, we need to scrutinize the moderating effects of exporter competition and foreign ownership. These two factors, however, might also act as either deterrents against or catalysts for a rapid start of export activities (see the dotted arrows in Figure 1). Therefore, to obtain statistically reliable results, it is imperative to control for the antecedents of entry speed before we proceed with tests on the entry-speed-exit relationship and the moderating effects. To do this, we adopt an approach similar to Heckman's (1979) two-step procedure (Mudambi and Zahra 2007).

In the first step, Model (1) estimates the entry-speed strategy:

$$
\operatorname{speed}_{i}=\alpha+\boldsymbol{\beta}^{*} \boldsymbol{X}_{i}+\varepsilon_{i}
$$

where speed $_{i}$ denotes how soon a firm starts its export business. $\boldsymbol{X}_{i}$ collectively represents a vector of the initial conditions of firm $i$, as the initial conditions will have an imprinting effect on subsequent firm behavior (Geroski et al. 2010; Hannan and Freeman 1989). The operationalization of the variables will be described in the next section.

In the second step, to estimate the probability of exiting from export markets, we use the Cox proportional hazards model (Cox 1972). An advantage of the Cox model is that it does not rely on assumptions about the form of the baseline hazard. More importantly, compared with a probit or logit model that just examines the probability of exit in year $t$, the Cox survival model estimates the conditional probability of exiting the export market in year $t$ given that the firm has survived in the export market for $t-1$ years. Cox's model has recently begun to be adopted more and more in business continuation analysis thanks to its statistical rigor (Geroski et al. 2010). The 
termination of exporting activity constitutes the exit event that we empirically test by using the Cox model. We employ a test stphplot in Stata and the results verify that the assumption of proportional hazards is not violated. A large portion of exporters continue with export activities in the final year of the sample period, and we have no knowledge of whether they will exit in the next year. This "right-censoring" issue can be dealt with by the Cox model effectively. The exit probability of each firm's exporting activity is assumed to follow its own hazard function, exit $t_{i t}$ :

$$
\text { exit }_{i t}=\operatorname{exit}_{i 0}{ }^{*} \exp \left(\delta+\eta^{*} \text { speed }_{i}+\boldsymbol{\gamma}^{*} \boldsymbol{Z}_{i t}+\xi_{i t}\right)
$$

where the dependent variable exitit is a conditional probability of full exit from all export destinations for the year $t$, given that the firm exports in the previous $t$-1 years, ranging between zero and one. exit $i_{i 0}$ is the baseline hazard without any prior assumption of functional form. $\boldsymbol{Z}_{i t}$ is a collection of variables that might affect the export hazard of firms. We use dynamic measures of firm conditions here, rather than initial conditions, as founding conditions tend to have a declining effect (Geroski et al. 2010), while existing conditions tend to change rapidly for startup firms, particularly after they have entered export markets that are rather different from their home market. The variables included in $\boldsymbol{Z}_{i t}$ will be described in the next section. As the variable speed $i$ included in Model (2) could be endogenously determined by its antecedents, we need to effectively control for this endogeneity issue to ensure that the coefficient $\eta$ for $s \widehat{p e e d}_{l}$ will be statistically unbiased:

$$
\text { exit }_{i t}=\operatorname{exit}_{i 0}{ }^{*} \exp \left(\delta+\eta^{*} \widehat{\operatorname{peed}}_{\iota}+\gamma^{*} \boldsymbol{Z}_{i t}+\xi_{i t}\right)
$$

where we replace speed $_{i}$ with the fitted value $\widehat{\text { peed }}_{\iota}$ predicted by Model (1). With this fitted variable, we may effectively remove the disturbing effects potentially caused by initial conditions of firm resources and industrial conditions i.e. firm size, productivity, exporter competition and 
foreign ownership in the foundation year of exporters (Mudambi and Zahra 2007; Sui and Baum 2014).

\subsection{Variables}

Entry speed, or earliness of exporting, is the time lag between a firm's inception and the first time it engages in international business (Oviatt and McDougall 1994; Sapienza et al. 2006). As our sample provides a sufficiently long period of observations, we adopt a continuous rather than a dichotomous variable measuring the speed of entry into the export market. It is operationalized by seven minus the number of years that elapsed between a firm's foundation and its initial exporting activity. This is a time-invariant variable for each firm, ranging from one to seven.

Exporter competition is inversely measured by the degree of export concentration in each industry. The operationalization of exporter competition is developed here in a way similar to a Herfindahl index:

$$
\text { Exporter competition }=1-\sum_{i=1}^{n}\left(\frac{\text { export }_{i}}{\sum_{i=1}^{n} \text { export }_{i}}\right)^{2}
$$

We first calculate a firm's export share in its three-digit industry sector in China in the observation year, and square this share. Then, we sum the squared export shares across all exporters in every sector-year group and deduct the sum from one. The larger the variable is, the higher the degree of competition between Chinese exporters in that particular sector will be. As a measure complementary to population density, this index not only measures competition but also inversely reflects the concentration of the monopolistic power of exporting activities. A similar index has been employed in the recent literature regarding competition and organizational ecology (Zhou and Li 2008). This index may capture the competitive dynamics caused by various industry-idiosyncratic factors such as firm ownership (Xu et al. 2014). 
Foreign ownership is measured by the share of foreign capital in a firm's total registered capital (Ilmakunnas and Nurmi 2010). We also include several firm-level variables that are widely documented in the literature to be important determinants of a firm's strategic behavior. Firm size is measured as the natural logarithm of the number of employees. Firm size can be positively related to the survival rate of a firm (Mata and Portugal 2002), as a larger firm is more likely to benefit from economies of scale, slack resources and extensive product lines (Almor et al. 2014; Glaister et al. 2014). Smaller firms might be more eager to escape the domestic market and rapidly explore overseas market opportunities too (Sui and Baum 2014). Another important control variable is firm productivity, which can proxy for overall management quality. This can be attributed to the prior experience of the entrepreneur, especially to his or her export experience. While recent international trade studies highlight the decisive role of firm productivity in determining a firm's capability to start exporting, exporter profitability and consequent export exit (Melitz 2003), they do not touch on the speed of entry into export markets. As less productive firms face stronger competition from domestic competitors, they will also be more likely to start exporting sooner and to pursue international opportunities, although they may face a higher exit risk than more productive exporters (Melitz 2003). The calculation of productivity employs the approach developed by Levinsohn and Petrin (LP) (2003). The LP approach takes into account the possible correlation between inputs and a state-dependent unobserved productivity disturbance. It uses intermediate inputs as a proxy for unobservable productivity shocks to effectively deal with the simultaneity problem. For these reasons, much of the recent business and management literature has employed the LP approach (e.g. Altomonte and Pennings 2009). We estimate the firm-level total factor productivity in each of the 30 twodigit manufacturing industries separately. 
In the extant literature on the antecedents of firm internationalization, it has been found that individual-level, firm-level and inter-organization-level factors such as resources, capabilities, international networks and shareholding, rivalry and imitation are important determinants leading to international entrepreneurship (Casillas and Acedo 2013; Delios et al. 2007; Kiss et al. 2012). As individual-level observations are not available for the current study that is based on secondary data, in the strategic model of entering the export market (Model (1)), we employ the values of exporter competition, foreign ownership, firm size and productivity in the inception year of each firm as the main antecedents $\left(\boldsymbol{X}_{i}\right)$, as well as 30 dummy variables controlling for regional factors. The inclusion of exporter competition and foreign ownership also serves to remove the potential self-selection endogeneity in the survival model.

In Model (3), the fitted value of entry speed is the main independent variable. A set of other explanatory variables $\left(\boldsymbol{Z}_{i t}\right)$ is provided as follows. Age has been found to be such an important factor leading to the mortality of new ventures that "it is extremely difficult to obtain useful estimates of ecological processes if aging is not taken into account" (Hannan and Freeman 1989, p. 245). As new ventures accumulate experience and overcome the liability of newness during their maturing process, the mortality rate may increase with a lower speed. Therefore, we also include a squared age term to reflect such nonlinearity.

Population density is measured with the number of startup exporters in each firm's industry, as the density represents the degree of legitimacy and niche width of organizations in that industry (Hannan and Freeman 1989, pp. 271-309). Product diversity measures how many broad types of products a firm produces. In the data collection survey, each firm was asked to write down up to three major product lines, so this variable takes a value between one and three. A more diversified product portfolio can, to a certain extent, effectively hedge against the 
uncertainty facing any individual product. As a control variable, product diversity also measures the capabilities of firms to adapt them for the market competition.

\section{Analysis and results}

\subsection{Descriptive analysis}

Figure 2 illustrates the different hazards facing "born exporters", "rapid exporters" and "slow exporters". Overall, the export continuation likelihood of born exporters is lower than that of rapid exporters, while the likelihood of rapid exporters is lower than that of slow exporters. The contrasts justify the liability of newness in the international context (Sleuwaegen and Onkelinx 2014), which is similar to the pronounced age dependence phenomenon found for domestic entrepreneurial firms in the organizational ecology literature (Freeman et al. 1983).

INSERT FIGURE 2 ABOUT HERE

Table 1 lists the frequencies of the different export timings, and the exit rates associated with them. For the whole sample of firms that start exporting within six years of inception, $9.1 \%$ start to export as soon as they set up their business. Another $60.3 \%$ start to export between one and three years after foundation. The exit rates for exporters are on average higher among rapid entrants and lower among slow entrants, which is consistent with the pattern illustrated in Figure 2. There is a high correlation between export market exit and firm closure, which is similar to the pattern exhibited in Finnish exporters (Ilmakunnas and Nurmi 2010). We also check the time lag between export exit and firm closure and find that $78.7 \%, 15.2 \%$ and $4.3 \%$ of exporters that exit from the export market will also close down the entire company in the same year, in the next year and in the third year, respectively. 


\section{INSERT TABLES $1 \& 2$ ABOUT HERE}

Table 2 reports the distribution of exporters and exit rates in the 30 two-digit industries. The industries with the lowest technological entry barriers, e.g. garments and textiles, host the largest cohort of exporting ventures. The average firm size of exporters does not exhibit a large amount of variation across industries. For every industry, the number of born and rapid exporters that start exporting within three years of foundation is at least $60 \%$ of the total number of exporters in that industry. Interestingly, the proportion of failed exporters among the rapid exporters is generally higher than that among the slow exporters, which is again consistent with the patterns illustrated in Figure 2 and Table 1. Tables 3 and 4 provide summary statistics and correlation coefficients for the main variables. All correlation coefficients between the independent variables are below 0.3 , suggesting there is no serious multicollinearity.

\section{INSERT TABLES $3 \& 4$ ABOUT HERE}

\subsection{Empirical results and robustness analyses}

Table 5 reports the determinants of the strategic choice of how soon to start exporting. The results of Model 1 suggest that smaller and less efficient firms tend to enter foreign markets more rapidly. This seems counterintuitive, but it may be linked with the government's protection of exporters in the form of quotas, subsidies and export tax rebates (Girma et al. 2009). Other things being equal, smaller and less efficient firms are perhaps more opportunistically eager to rely on institutional support to explore overseas markets than their larger and more efficient counterparts that are in a more advantageous position in their home market (Khandelwal et al. 2013). 
Canadian small and medium-sized exporters have been found to exhibit a similar pattern in their relationship between entry speed and firm size and productivity level (Sui and Baum 2014).

When the degree of exporter competition is high (or the concentration degree is low), firms will be deterred by the competition in the market and will tend to wait longer to enter the foreign market and join the competition, which echoes the findings of Delios et al. (2007) and Burke and van Stel (2014). Finally, foreign ownership induces firms to become exporters rapidly, thanks to the facilitating effects of foreign investors. This is consistent with the finding of Musteen et al. (2010) on the positive relationship between international ties and entry speed.

INSERT TABLE 5 ABOUT HERE

Table 6 presents the results obtained from the Cox model regressions. Models 1 to 5 use a conventional model without controlling for the endogeneity effect of entry speed, while Models 6 to 10 use, as an instrumental variable, the fitted value of entry speed obtained from Model 1 in Table 5. They produce generally consistent results. We will mainly discuss the results of Models 6 to 10. Coefficients greater than zero are interpreted as an increment in the likelihood of exiting, as the dependent variable is the conditional probability of the exporter's exit from the international market; meanwhile, negative coefficients are interpreted as a reduction in this likelihood. For example, in Model 6, a one-year increase in entry speed increases the hazard by $12.0 \%$ because $\exp (0.113)=1.120$. These two models generate highly consistent results. The significantly positive coefficients of entry speed in Models 1 and 6 support $\mathrm{H} 1$ and confirm the positive impact of rapid entry on exit, as illustrated in Figure 2. The coefficients of size, product 
diversity, productivity and population density are all significantly negative, which means that these variables can effectively reduce the likelihood of exit.

In particular, when combining the results of Model 1 (Table 5) and Model 6 (Table 6), we can see that small and inefficient new ventures tend to enter export markets rapidly, but unfortunately face higher exit risks, exhibiting the brutal market selection effect in the international market. This finding echoes recent international trade theory, which argues that only the most productive firms can afford the high entry sunk cost involved in exporting (Melitz 2003). Age and its squared term have positive and negative coefficients, respectively, suggesting the nonlinear impact of age on exit, consistent with the pattern exhibited in Figure 2.

\section{INSERT TABLE 6 ABOUT HERE}

With the same set of explanatory variables, we find that age and age squared only account for $1.2 \%$ of the variance, while entry speed accounts for $8.3 \%$ of the variance of Model 1 , according to the analysis of variance (ANOVA) (Makino et al. 2004; McGahan and Porter 1997). That difference suggests the entry-speed, despite a static initial factor, still exerts a strong and long-lasting effect on the subsequent exit from exporting. We also compare the sample of exporters with that of domestic firms. We confine domestic firms to those entrepreneurial, indigenous ones, i.e. with less than 250 employees, established after 1997, with less than 50\% foreign ownership, and without state ownership. Age and age squared jointly account for $0.18 \%$ of the model variance, lower than that in the young exporter scenario. That difference suggests the liability of newness seems to play a more significant role in affecting firm exits in the crossborder context. 
Models 7 to 10 extend Model 6 by including exporter competition and foreign ownership as moderators. This study does not include moderating variables in the regressions through multiplication, as interpreting the coefficients of interaction terms in nonlinear models such as logit and Cox models is error-prone, while the actual effects of the explanatory and moderating variables depend not only on their estimated coefficients but also on the coefficients and values of other regressors (Wiersema and Bowen 2009). Moreover, pooling the whole sample together and running regressions collectively assumes implicitly that the observed variation is the same between the different groups. To avoid the above complications and biases, this study follows the more intuitive practice of Lamin and Livanis (2013) and dichotomizes the sample into two subsamples, below and above the median value of exporter competition, in Models 7 and 8 , respectively. By comparing the coefficients of entry speed in two separate models, we are able to identify the moderating effect straightforwardly. Similarly, Models 9 and 10 provide a comparative study of the two subsamples with and without foreign investors.

Entry speed under high exporter competition (corresponding to low exporter concentration) in Model 8 leads to a lower exit probability, while low exporter competition (corresponding to high exporter concentration) in Model 7 makes it more likely that exporters will exit, which echoes the findings of Puig et al. (2014). These differentiated results highlight the long-lasting and polarizing effects of early exporting on exit, which substantiates H2. The coefficient of the exporter competition variable is negative in Models 6, 9 and 10, suggesting that high competition (low concentration) can stimulate exporters to improve their productivity and enhance their ability to survive.

If we collate the opposing effects of exporter competition in the pre- and post-entry scenarios shown in Model 1 (Table 5) and Models 7 and 8 (Table 6), we will have a holistic 
understanding of the polarizing role of competition and early exporting in separating out superior firms from inferior ones in the evolution of organizational ecology (Hannan and Freeman 1989). The negative coefficient of exporter competition in Model 1 (Table 5) suggests that competition between exporters will deter potential entrants from rapid entry. This will slow down the exporting pace of firms and help firms accumulate market experience as well as build internal routines and external networks, first, in the home market. When a firm decides to join an export market in which market power is evenly distributed, rapid entry will enable it to occupy a market niche more effectively than in the scenario of low competition (high concentration) (McAran 2009). In other words, firms internationalize for a better prosperity (Puig et al. 2014). On the other hand, if competition is low and export activities are relatively concentrated, potential entrants will more likely be induced to rush into export activities. As dominant exporters will have stronger monopolistic power in this scenario, rapid entry will be harmful to startups because they lack sufficient vigilance regarding market conditions (Burke and van Stel 2014). Therefore, the moderating effect of competition on the relationship between speed and exit reflects the enabling effect of strong competition (low concentration) and the selective effect of weak competition (high concentration) in the international entrepreneurship context.

In Models 9 and 10, the regression results for firms with and without foreign ownership are reported (60.7\% of the whole sample). With the presence of foreign ownership, a higher entry speed will lead to a lower exit rate, while in the absence of foreign ownership rapid entry will lead to a significantly higher exit rate. This contrast justifies H3, suggesting that by building shareholding partnerships with foreign firms, a young exporter can equip itself with strong ties with international markets, and its learning effect will become rather prominent as a result. The more rapidly it enters the export market, the less likely it is that it will discontinue its 
international business. Taking into consideration the positive impact of foreign ownership on the speed of entry into the export market, as suggested by Model 1 (Table 5), we find that strategically building shareholding partnerships with foreign investors generates a significant adaptation effect. To be more specific, foreign investors will help domestic firms to perform systematic market analyses and provide them with a strong branding effect, both of which will help them to enter foreign markets rapidly. Once they start their foreign operations, rapid-entry exporters will enjoy the learning effects and international networks of their foreign investors.

\subsection{Robustness tests}

To test the robustness of the empirical findings, we run various robustness tests to control for disturbances that could be caused by sample dependence and industrial technology intensity. The first set of robustness tests check sample independence, i.e. whether the strategic choice model in the first stage is fully independent of the Cox model in the second stage. We randomly split the sampled exporters into two parallel groups. We use the first group to estimate the strategic choice of rapid entry. With the fitted value of entry speed estimated, we use the second group to estimate the Cox model. The split-sample procedure has the advantage of excluding estimate bias (Angrist and Krueger 1995), controlling for type 1 error (Bolduc et al. 2008) and obtaining reliable coefficients (Dufour and Jasiak 2001). The results of the strategic choice analysis are reported in Table 5 (Model 2), while the estimates of the Cox analyses are reported in Table 7 (Models 2-6). Model 1 (Table 7), in which the endogeneity of entry speed is not controlled for, is reported too, for comparative purposes. We can see that the new results are generally similar to the previous ones obtained without using the split-sample procedure. The speed variable no longer has a significant effect on exit, suggesting that, as long as firm resources and industrial conditions are favorable for exporters, the speed of entry does not matter, which is consistent with the finding of 
Mudambi and Zahra (2007). When we split the second subsample based on exporter competition and foreign ownership, we obtain results that are highly consistent with those in Table 6, supporting $\mathrm{H} 2$ and $\mathrm{H} 3$.

\section{INSERT TABLES $7 \& 8$ ABOUT HERE}

The second set of robustness tests checks whether industrial technology intensity affects the validity of the empirical findings. The discussion in Section 3.2 suggests that, in rapidly emerging sectors such as the manufacturing of advanced telecommunication equipment and other high-technology-based sectors, a market niche can be globally distributed and can quickly become obsolete. Therefore, rapid entry may bring about a greater market opportunity for postentry continuation and success. Such an opportunity may partially alleviate the negative shocks caused by the liabilities of newness, rapidness and foreignness. Moreover, technology intensity may amplify the learning advantage of newness for nascent exporters so that they may learn faster from their rivals and customers (Autio et al. 2000). Finally, technological advancement grants high-technology exporters a certain degree of legitimacy in the international arena, which may counterbalance the relatively weak branding of exporters' products. We run the robustness tests by breaking the sample into high- and low-technology industries, according to the industrial classification of the NBS. This classification treats 59 out of 480 four-digit manufacturing sectors as high-tech ones and is generally compatible with the widely used OECD high/low-technology industry dichotomy (OECD 2011). The comparison of the empirical results in Table 8 shows that these two types of industries exhibit similar patterns, and that all the theoretical hypotheses are supported, despite tiny differences. Entry speed does not have a significant impact on the exit of 
high-technology exporters in Model 6, confirming our proposition that knowledge intensity has a partial alleviation effect. This finding is consistent with that in Model 9, suggesting that, even without foreign ownership, exporters will observe a rather neutral relationship between entry speed and exit thanks to the legitimation effect of technological resources.

\section{Conclusion}

This study examines the relationship between timing or speed of entry into export markets, and exit from them. While theories on international entrepreneurship argue in favor of the learning advantage of newness, the process model of internationalization warns of the tremendous risks of rapidly entering overseas markets, caused by the triple liability of rapidness, newness and foreignness. So far, our understanding of the exit rates after rapid entry into the export market is rather limited. By leveraging the lens of organizational ecology theory, this study addresses this limitation and examines the effect of entry speed on exit for startups, after statistically controlling for the strategic choice of entry speed. In addition, it examines the effect of moderating factors, i.e. exporter competition and foreign ownership, on the link between early exporting and exit.

The findings show that rapid entry into the export market is generally not helpful for young ventures to sustain their overseas business. This echoes the process model of internationalization. It also confirms that the founding conditions of export projects (i.e. earliness of exporting) have a marked effect on their termination (Geroski et al. 2010). Our results also show that the rapid-entry strategy may have polarizing effects under different conditions. Strong exporter competition may enhance the probability of rapid entrants staying in the export market, while weak competition will exert a negative effect. While traditional organizational ecology scholars argue that intensive competition may reduce new ventures' continuation chances due to competition for limited resources, our results show that early competition strengthens new 
ventures' capability of identifying and capturing market niches, learning from rivals and building an efficiency-based corporate routine. Our finding is consistent with recent research on early competition's immunizing effect on new ventures (Burke and Hussel 2013). Foreign ownership may also increase the continuation probability in the case of early exporting, indicating that building international shareholding partnerships may be an effective adaptive strategy for reducing risk and acquiring isomorphism.

This study makes several theoretical contributions. First, it broadens the literature on international entrepreneurship by identifying roles that ecological conditions play in export exit. It is the first in the literature to examine the effect of earliness, as a founding condition of export projects, on exit. It also scrutinizes the two important contingency conditions for exit, namely market selection and firm adaptation in organizational ecology (Hannan and Freeman 1989). To some extent, it reconciles the difference between the process model and international entrepreneurship theory, as it examines the conditions under which early entry into export markets may be a favorable or hazardous foreign-entry strategy for a startup firm, i.e. the polarizing effect of early exporting on exit. The findings suggest that both founding and current conditions are important for project duration (Geroski et al. 2010). The paper echoes the recent call for a "more pluralistic treatment of uncertainty" involved in internationalization (Liesch et al. 2011, p. 869) and deepens our understanding of the effect of an early-exporting strategy on exit.

Second, following the research paradigm in organizational ecology, this study is the first in the literature of international entrepreneurship that holistically examines the entire life cycle of nascent exporters from inception to international venturing and eventually exit from the export market. By integrating the analyses of both the antecedents and the consequences of rapid international venturing, we offer new insights. We find that exporter competition will deter firms 
from entering export markets rapidly. However, once a young exporter has prepared itself and if it enters this market rapidly with strong exporter competition (low concentration), such an aggressive strategy will help improve the "gene" (Almor et al. 2014) and the exporting business will be sustained for longer. Interestingly, small and inefficient new ventures tend to start exporting rapidly, although such exporters will be more likely to exit the export markets later on, manifesting the amplified selection effect of international entrepreneurship in the ecology of organizations. Our study calls for a long-term perspective in international entrepreneurship, examining both antecedents and consequences.

The study also extends the theory of organizational ecology in an international setting. Most of the extant organizational ecology literature focuses on domestic business scenarios (Hannan and Freeman 1989; Xu et al. 2014). By scrutinizing the enabling mechanism of foreign ownership on entrepreneurial exporters, we obtain new findings on the evolution and symbiosis between different population ecologies (Xu et al. 2014). We find dynamic interactions to occur not only domestically but also internationally. An important ecological evolution, namely firm adaptation with foreign ownership, grants startups legitimacy in foreign markets, helping early exporters to become market insiders and to sustain their business in these markets (Johanson and Vahlne 2009), which is in line with the recent stream of research on the network effect between the most illegitimate form (startup exporters) and the most legitimate insiders (multinational enterprises) in international markets (Musteen et al. 2010). We also find that small and inefficient new ventures tend to enter export markets rapidly but unfortunately face higher exit risks, exhibiting the more significant market selection effect in the international market.

Nonetheless, this study has limitations that need to be taken into consideration when interpreting and generalizing its findings. First, the competition environment in the host country 
ecology is not fully explored due to data unavailability, although competition among exporters from the same country of origin and the same industry is highly relevant (Delios et al. 2007). Second, our findings may not be generalizable to small economies whose exporters do not have an influential market share in the host market. Also, this single-country study may not completely control for country-level characteristics such as size of population, institutional environment and technological advancement. Third, exporting has many categories, such as direct versus indirect exporting and general versus assembly trade exporting. Different forms of exporting involve different levels of exit risks. For example, it is relatively easy and less risky to engage in indirect exporting, but indirect exporters may be less productive and therefore more vulnerable to external uncertainty, too (Ahn et al. 2011). Therefore, we would need more detailed data to test this issue. Fourth, a startup firm may enter foreign markets through multiple modes simultaneously, such as exporting, alliances and FDI. Because different modes will lead firms to encounter different liabilities of foreignness, it may be an interesting avenue to study these alternative entry modes, even though exporting remains the dominant entry mode of young ventures (Knight and Cavusgil 2004). Finally, due to data limitations, we cannot pin down the country of origin of each foreign investor. While foreign investors generally grant foreign knowledge and market legitimacy to exporters, foreign investors from the host country may provide even stronger help.

The results of this study convey important messages for practitioners. Generally speaking, rapid exporting may be a highly risky strategy for new startups despite the potential learning advantage of the newness of exporters. Nowadays, modern information technologies and lower trade barriers have opened a new window of overseas opportunities for nascent firms (Oviatt and McDougall 1994; Sinkovics et al. 2013). Lured by the prospects of going international, young startups, particularly those from emerging economies that have recently been deregulated and 
integrated into the global economy (Kiss et al. 2012), tend to be enthusiastic about expanding into international markets. However, the premature expansion of businesses into unfamiliar international markets may be dangerous, as enterprises might not have accumulated enough market experience, branding or financial resources to overcome the tremendous triple liability of rapidness, newness and foreignness (Gabrielsson et al. 2014; Nummela et al. 2014).

Despite acknowledging the high probability of post-entry discontinuation after rapid entry into export markets, this study offers two strategic prescriptions. First, if startups face intense exporter competition and low market concentration, the exporters will need to keep strategically alert from inception, build organizational routines compatible with the competitive environment in international markets early on, and improve their product quality and management efficiency. By doing so, early-exporting firms may seize niche market opportunities, and stay longer in foreign markets (Puig et al. 2014). Second, by hosting foreign investment, particularly from prestigious MNEs, startup exporters may adapt themselves to managing the risks and uncertainties in international markets by leveraging international distribution networks, bestpractice experiences and the international legitimacy of foreign investors (Brouthers et al. 2013).

\section{References}

Ahn, J., Khandelwal, A. K., \& Wei, S.-J. (2011). The role of intermediaries in facilitating trade. Journal of International Economics, 84(1), 73-85.

Almor, T., Tarba, S., \& Margalit, A. (2014). Maturing, technology-based, born-global companies: Surviving through mergers and acquisitions. Management International Review, 54(4), 421-444.

Altomonte, C., \& Pennings, E. (2009). Domestic plant productivity and incremental spillovers from foreign direct investment. Journal of International Business Studies, 40(7), 1131-1148.

Andries, P., \& Debackere, K. (2007). Adaptation and performance in new businesses: Understanding the moderating effects of independence and industry. Small Business Economics, 29(1-2), 81-99.

Angrist, J. D., \& Krueger, A. B. (1995). Split-sample instrumental variables estimates of the returns to schooling. Journal of Business and Economic Statistics, 13(2), 225-235.

Autio, E., Sapienza, H. J., \& Almeida, J. G. (2000). Effects of age at entry, knowledge intensity, and imitability on international growth. Academy of Management Journal, 43(5), 909-924.

Benito, G. R. G., \& Welch, L. S. (1997). De-internationalization. Management International Review, 37(Internationalization Processes - New Perspectives for a Classical Field of International Management), 7-25. 
Bolduc, D., Khalaf, L., \& Moyneur, E. (2008). Identification-robust simulation-based inference in joint discrete/continuous models for energy markets. Computational Statistics and Data Analysis, 52(6), 3148-3161.

Brouthers, L. E., O’Donnell, E., \& Keig, D. L. (2013). Isomorphic pressures, peripheral product attributes and emerging market firm export performance. Management International Review, 53(5), 687-710.

Burke, A., \& Hussel, S. (2013). How competition strengthens start-ups. Harvard Business Reviev, 91(3), 24.

Burke, A., \& van Stel, A. (2014). Entry and exit in disequilibrium. Journal of Business Venturing, 29(1), 174-192.

Carr, J. C., Haggard, K. S., Hmieleski, K. M., \& Zahra, S. A. (2010). A study of the moderating effects of firm age at internationalization on firm survival and short-term growth. Strategic Entrepreneurship Journal, 4(2), 183-192.

Casillas, J. C., \& Acedo, F. J. (2013). Speed in the internationalization process of the firm. International Journal of Management Reviews, 15(1), 15-29.

Chang, S. J., \& Xu, D. (2008). Spillovers and competition among foreign and local firms in China. Strategic Management Journal, 29(5), 495-518.

Chen, M.-J. (1996). Competitor analysis and interfirm rivalry: Toward a theoretical integration. The Academy of Management Review, 21(1), 100-134.

Cleves, M. A., Gould, W. W., \& Gutierrez, R. G. (2004). An introduction to survival analysis using stata (Revised ed.). College Station, Texas: Stata Press.

Cox, D. R. (1972). Regression models and life-tables. Journal of the Royal Statistical Society. Series B (Methodological), 34(2), 187-220.

Crick, D. (2004). U.K. SMEs' decision to discontinue exporting: An exploratory investigation into practices within the clothing industry. Journal of Business Venturing, 19(4), 561-587.

Delios, A., Gaur, A. S., \& Makino, S. (2007). The timing of international expansion: Information, rivalry and imitation among Japanese firms, 1980-2002. Journal of Management Studies, 45(1), 169-195.

Dufour, J.-M., \& Jasiak, J. (2001). Finite sample limited information inference methods for structural equations and models with generated regressors. International Economic Review, 42(3), 815-843.

Efrat, K., \& Shoham, A. (2012). Born global firms: The differences between their short- and long-term performance drivers. Journal of World Business, 47(4), 675-685.

Eriksson, K., Johanson, J., Majkgard, A., \& Sharma, D. D. (1997). Experiential knowledge and costs in the internationalization process. Journal of International Business Studies, 28(2), 337-360.

Freeman, J., Carroll, G. R., \& Hannan, M. T. (1983). The liability of newness: Age dependence in organizational death rates. American Sociological Review, 48(5), 692-710.

Gabrielsson, M., Gabrielsson, P., \& Dimitratos, P. (2014). International entrepreneurial culture and growth of international new ventures. Management International Review, 54(4), 445-471.

Geroski, P. A., Mata, J., \& Portugal, P. (2010). Founding conditions and the survival of new firms. Strategic Management Journal, 31(5), 510-529.

Girma, S., Gong, Y., Görg, H., \& Yu, Z. (2009). Can production subsidies explain China's export performance? Evidence from firm-level data. Scandinavian Journal of Economics, 111(4), 863-891.

Glaister, A., Liu, Y., Sahadev, S., \& Gomes, E. (2014). Externalizing, internalizing and fostering commitment: The case of born-global firms in emerging economies. Management International Review, 54(4), 473-496.

Hagen, B., \& Zucchella, A. (2014). Born global or born to run? The long-term growth of born global firms. Management International Review, 54(4), 497-525.

Hannan, M. T., \& Freeman, J. (1977). The population ecology of organizations. American Journal of Sociology, 82(5), 929-964.

Hannan, M. T., \& Freeman, J. (1989). Organizational ecology. Cambridge, MA: Harvard University Press.

Heckman, J. (1979). Sample selection bias as a specification error. Econometrica, 47(1), 153-161. 
Ilmakunnas, P., \& Nurmi, S. (2010). Dynamics of export market entry and exit. Scandinavian Journal of Economics, 112(1), 101-126.

Isenberg, D. J. (2008). The global entrepreneur. Harvard Business Review, 86(12), 107-111.

Javalgi, R. G., Todd, P. R., \& Scherer, R. F. (2005). The dynamics of global e-commerce: An organizational ecology perspective. International Marketing Review, 22(4), 420-435.

Javorcik, B. S. (2004). Does foreign direct investment increase the productivity of domestic firms? In search of spillovers through backward linkages. American Economic Review, 94(3), 605-627.

Johanson, J., \& Vahlne, J.-E. (1977). The internationalization process of the firm--a model of knowledge development and increasing foreign market commitments. Journal of International Business Studies, 8(1), 23-23.

Johanson, J., \& Vahlne, J.-E. (2009). The Uppsala internationalization process model revisited: From liability of foreignness to liability of outsidership. Journal of International Business Studies, 40(9), 1411-1431.

Jones, M. V., Coviello, N., \& Tang, Y. K. (2011). International entrepreneurship research (1989-2009): A domain ontology and thematic analysis. Journal of Business Venturing, 26(6), 632-659.

Jones, M. V., \& Coviello, N. E. (2005). Internationalisation: Conceptualising an entrepreneurial process of behaviour in time. Journal of International Business Studies, 36(3), 284-303.

Keil, T. (2004). Building external corporate venturing capability. Journal of Management Studies, 41(5), 799-825.

Khandelwal, A. K., Schott, P. K., \& Wei, S.-J. (2013). Trade liberalization and embedded institutional reform: Evidence from Chinese exporters. American Economic Review, 103(6), 2169-2195.

Khavul, S., Pérez-Nordtvedt, L., \& Wood, E. (2010). Organizational entrainment and international new ventures from emerging markets. Journal of Business Venturing, 25(1), 104-119.

Kiss, A. N., Danis, W. M., \& Cavusgil, S. T. (2012). International entrepreneurship research in emerging economies: A critical review and research agenda. Journal of Business Venturing, 27(2), 266-290.

Knight, G. A., \& Cavusgil, S. T. (2004). Innovation, organizational capabilities, and the born-global firm. Journal of International Business Studies, 35(2), 124-141.

Kuivalainen, O., Sundqvist, S., \& Servais, P. (2007). Firms' degree of born-globalness, international entrepreneurial orientation and export performance. Journal of World Business, 42(3), 253-267.

Lamin, A., \& Livanis, G. (2013). Agglomeration, catch-up and the liability of foreignness in emerging economies. Journal of International Business Studies, 44(6), 579-606.

Levinsohn, J., \& Petrin, A. (2003). Estimating production functions using inputs to control for unobservables. Review of Economic Studies, 70(2), 317-341.

Li, J., Yang, J. Y., \& Yue, D. R. (2007). Identity community, and audience: How wholly owned foreign subsidiaries gain legitimacy in China. Academy of Management Journal, 50(1), 175-190.

Liesch, P. W., Welch, L. S., \& Buckley, P. J. (2011). Risk and uncertainty in internationalisation and international entrepreneurship studies. Management International Review, 51(6), 851-873.

Makino, S., Isobe, T., \& Chan, C. M. (2004). Does country matter? Strategic Management Journal, 25(10), 1027-1043.

Mata, J., \& Portugal, P. (2002). The survival of new domestic and foreign-owned firms. Strategic Management Journal, 23(4), 323-343.

McAran, D. (2009). The global entrepreneur. Harvard Business Review, 87(5), 124-125.

McDougall, P. P., \& Oviatt, B. M. (2000). International entrepreneurship: The intersection of two research paths. Academy of Management Journal, 43(5), 902-906.

McGahan, A. M., \& Porter, M. E. (1997). How much does industry matter, really? Strategic Management Journal, 18(S1), 15-30.

McNaughton, R. B. (2003). The number of export markets that a firm serves: Process models versus the born-global phenomenon. Journal of International Entrepreneurship, 1(3), 297-311.

Melitz, M. (2003). The impact of trade on intra-industry reallocations and aggregate industry productivity. Econometrica 71, 1695-1725. 
Mishkin, S., \& Clover, C. (2014). Intel turns to Chinese tablet makers: in Financial Times.

Moen, Ø., \& Servais, P. (2002). Born global or gradual global? Examining the export behavior of small and medium-sized enterprises. Journal of International Marketing, 10(3), 49-72.

Mudambi, R., \& Zahra, S. A. (2007). The survival of international new ventures. Journal of International Business Studies, 38(2), 333-352.

Musteen, M., Francis, J., \& Datta, D. K. (2010). The influence of international networks on internationalization speed and performance: A study of Czech SMEs. Journal of World Business, 45(3), 197-205.

Nickel, M. N., \& Fuentes, J. M. (2004). Relationship between legitimation, competition and organizational death: Current state of the art. International Journal of Management Reviews, 5(1), 43-62.

Nordman, E. R., \& Melén, S. (2008). The impact of different kinds of knowledge for the internationalization process of born globals in the biotech business. Journal of World Business, 43(2), 171-185.

Nummela, N., Saarenketo, S., Jokela, P., \& Loane, S. (2014). Strategic decision-making of a born global: A comparative study from three small open economies. Management International Review, 54(4), $527-550$.

OECD (2011). Isic rev. 3 technology intensity definition: Classification of manufacturing industries into categories based on R\&D intensities. Paris: OECD.

Oviatt, B., \& McDougall, P. (1994). Toward a theory of international new ventures. Journal of International Business Studies, 25(1), 45-45.

Porter, M. E. (1980). Competitive stratey: Techniques for analyzing industries and competitors. New York: Free Press.

Porter, M. E. (1990). The competitive advantage of nations. New York: Free Press.

Puig, F., González-Loureiro, M., \& Ghauri, P. (2014). Internationalisation for survival: The case of new ventures. Management International Review, 54(5), 653-673.

Rosenzweig, P. M., \& Singh, J. V. (1991). Organization environments and the multinational enterprise. Academy of Management Review, 16(2), 340-361.

Sapienza, H. J., Autio, E., George, G., \& Zahra, S. A. (2006). A capabilities perspective on the effects of early internationalization on firm survival and growth. Academy of Management Review 31(4), 914933.

Shane, S. (2000). Prior knowledge and the discovery of entrepreneurial opportunities. Organization Science, 11(4), 448-469.

Sinkovics, N., Sinkovics, R. R., \& Jean, R. J. B. (2013). The internet as an alternative path to internationalization? International Marketing Review, 30(2), 130-155.

Sleuwaegen, L., \& Onkelinx, J. (2014). International commitment, post-entry growth and survival of international new ventures. Journal of Business Venturing, 29(1), 106-120.

Sui, S., \& Baum, M. (2014). Internationalization strategy, dynamic capabilities, and the survival of SMEs in the export market. Journal of International Business Studies, 45(7), 821-841.

Uberbacher, F. (2014). Legitimation of new ventures: A review and research programme. Journal of Management Studies, 51(4), 667-698.

UNCTAD (2013). World investment report 2013. Global value chains: Investment and trade for development. Geneva: UNCTAD.

Vahlne, J. E., \& Johanson, J. (2013). The Uppsala model on evolution of the multinational business enterprise - from internalization to coordination of networks. International Marketing Review, 30(3), 189-210.

Vermeulen, F., \& Barkema, H. (2002). Pace, rhythm, and scope: Process dependence in building a profitable multinational corporation. Strategic Management Journal, 23(7), 637-653.

Welch, C. L., \& Welch, L. S. (2009). Re-internationalisation: Exploration and conceptualisation. International Business Review, 18(6), 567-577. 
Wiersema, M. F., \& Bowen, H. P. (2009). The use of limited dependent variable techniques in strategy research: Issues and methods. Strategic Management Journal, 30(6), 679-692.

Wiklund, J., Baker, T., \& Shepherd, D. (2010). The age-effect of financial indicators as buffers against the liability of newness. Journal of Business Venturing, 25(4), 423-437.

Xu, D., Lu, J. W., \& Gu, Q. (2014). Organizational forms and multi-population dynamics: Economic transition in China. Administrative Science Quarterly, 59(3), 517-547.

Yamin, M., \& Sinkovics, R. R. (2006). Online internationalisation, psychic distance reduction and the virtuality trap. International Business Review, 15(4), 339-360.

Zahra, S. A., Ireland, R. D., \& Hitt, M. A. (2000). International expansion by new venture firms: International diversity, mode of market entry, technological learning, and performance. Academy of Management Journal, 43(5), 925-950.

Zhan, W., \& Luo, Y. (2008). Performance implications of capability exploitation and upgrading in international joint ventures. Management International Review, 48(2), 227-253.

Zhou, C., \& Li, J. (2008). Product innovation in emerging market-based international joint ventures: An organizational ecology perspective. Journal of International Business Studies, 39(7), 1114-1132. 


\section{Figures}

Figure 1. Conceptual framework

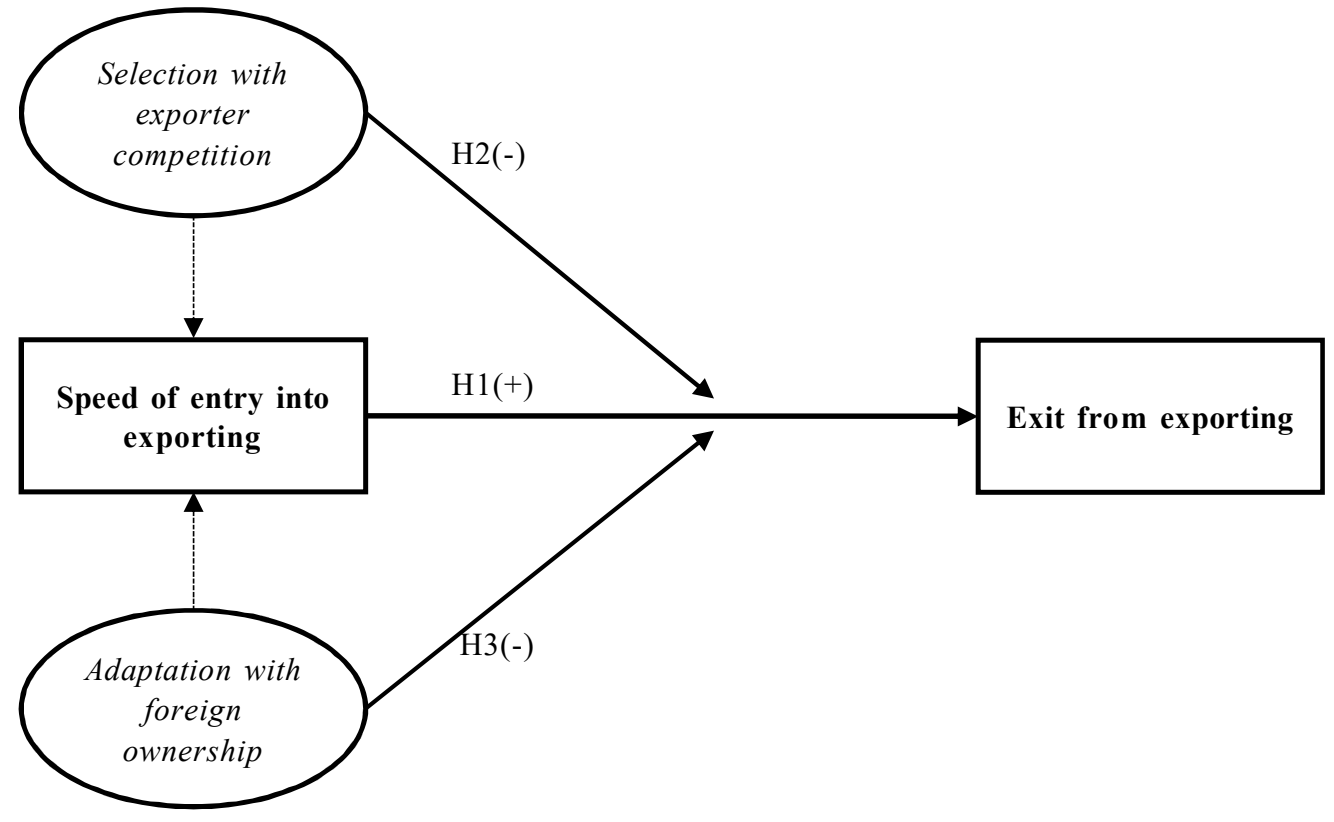

Figure 2. Exits of born, rapid and slow exporters

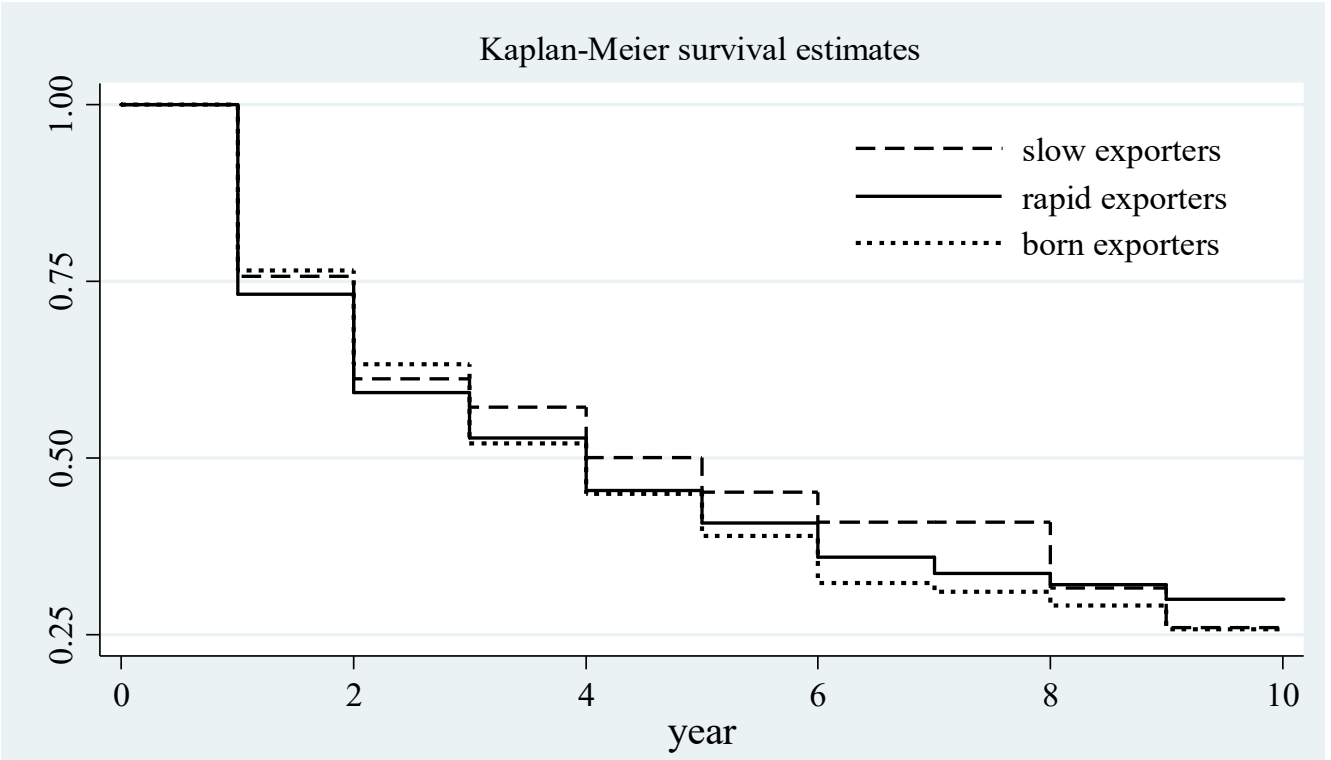

Note: The vertical axis denotes the probability of continuing to operate in export markets. An exporter is in the "born exporters" cohort if it starts exporting in the year of its foundation. An exporter is in the "rapid exporters" cohort if it starts exporting within 1-3 years of its foundation. Otherwise, it is in the "slow entrants" cohort. 


\section{Tables}

Table 1. Entry timing and exit

\begin{tabular}{ccccccc}
\hline $\begin{array}{c}\text { Years before } \\
\text { initial export }\end{array}$ & $\begin{array}{c}\text { No. of } \\
\text { obs }\end{array}$ & $\%$ & $\begin{array}{c}\% \text { of } \\
\text { export exits }\end{array}$ & $\begin{array}{c}\text { \% of firm } \\
\text { closures }\end{array}$ & $\begin{array}{c}\text { Years from } \\
\text { exit to closure }\end{array}$ & $\begin{array}{c}\text { Correlation btw } \\
\text { exit and closure }\end{array}$ \\
\hline 0 & 12,203 & 9.1 & 42.0 & 37.9 & 0.23 & 0.83 \\
1 & 27,586 & 20.6 & 48.8 & 40.1 & 0.31 & 0.76 \\
2 & 27,917 & 20.9 & 44.7 & 35.5 & 0.33 & 0.75 \\
3 & 25,106 & 18.8 & 43.2 & 33.6 & 0.33 & 0.73 \\
4 & 18,962 & 14.2 & 41.4 & 31.5 & 0.29 & 0.70 \\
5 & 13,062 & 9.8 & 41.6 & 31.2 & 0.31 & 0.68 \\
6 & 8,792 & 6.6 & 38.5 & 29.7 & 0.30 & 0.63 \\
All & 133,626 & 100.0 & 43.8 & 34.7 & 0.31 & 0.73 \\
\hline
\end{tabular}

Table 2. Industry distribution of exporters and exit rates

\begin{tabular}{|c|c|c|c|c|c|c|}
\hline Two-digit industry & $\begin{array}{r}\text { No. of } \\
\text { obs }\end{array}$ & $\begin{array}{r}\text { Average } \\
\text { no. of } \\
\text { employees }\end{array}$ & $\begin{array}{c}\% \text { of born } \\
\& \text { rapid } \\
\text { exporters }\end{array}$ & $\begin{array}{r}\% \text { of exits } \\
\text { among born \& } \\
\text { rapid exporters }\end{array}$ & $\begin{array}{r}\% \text { of slow } \\
\text { exporters }\end{array}$ & $\begin{array}{r}\% \text { of exits } \\
\text { among slow } \\
\text { exporters }\end{array}$ \\
\hline food processing & 6,126 & 89 & 70.3 & 55.1 & 29.7 & 51.8 \\
\hline food & 2,417 & 99 & 72.3 & 52.9 & 27.7 & 50.6 \\
\hline beverages & 859 & 84 & 70.0 & 60.3 & 30.0 & 61.5 \\
\hline tobacco & 8 & 127 & 100.0 & 75.0 & 0.0 & - \\
\hline textiles & 14,175 & 111 & 70.0 & 44.0 & 30.0 & 40.1 \\
\hline garments & 13,998 & 131 & 75.3 & 46.1 & 24.7 & 41.8 \\
\hline leather & 5,981 & 130 & 74.2 & 43.3 & 25.8 & 42.7 \\
\hline wood & 3,228 & 99 & 71.0 & 50.3 & 29.0 & 46.6 \\
\hline furniture & 2,922 & 114 & 74.2 & 38.1 & 25.8 & 35.0 \\
\hline papermaking & 1,566 & 107 & 64.0 & 58.8 & 36.0 & 46.4 \\
\hline printing & 759 & 109 & 60.2 & 48.1 & 39.8 & 48.7 \\
\hline culture \& sport goods & 3,922 & 113 & 70.0 & 40.1 & 30.0 & 33.3 \\
\hline petroleum & 163 & 90 & 65.9 & 83.9 & 34.1 & 75.9 \\
\hline chemical materials & 7,064 & 92 & 67.0 & 52.6 & 33.0 & 42.9 \\
\hline pharmaceutical & 1,580 & 101 & 71.2 & 57.6 & 28.8 & 47.5 \\
\hline chemical fibers & 422 & 116 & 73.3 & 50.6 & 26.7 & 49.2 \\
\hline rubber & 1,348 & 110 & 66.3 & 38.5 & 33.7 & 41.6 \\
\hline plastic & 6,764 & 104 & 66.0 & 40.8 & 34.0 & 38.7 \\
\hline non-metal minerals & 6,057 & 108 & 67.4 & 54.3 & 32.6 & 51.5 \\
\hline ferrous metals & 942 & 103 & 71.4 & 59.7 & 28.6 & 54.6 \\
\hline nonferrous metals & 1,525 & 100 & 67.7 & 56.3 & 32.3 & 53.1 \\
\hline metal products & 8,838 & 105 & 67.8 & 43.3 & 32.2 & 38.4 \\
\hline general equipment & 8,231 & 103 & 62.0 & 37.4 & 38.0 & 36.5 \\
\hline special equipment & 4,633 & 102 & 64.2 & 39.3 & 35.8 & 37.3 \\
\hline transport equipment & 4,521 & 110 & 66.9 & 41.2 & 33.1 & 41.7 \\
\hline electric machinery & 8,700 & 109 & 69.1 & 40.9 & 30.9 & 38.7 \\
\hline electronic equipment & 5,351 & 121 & 64.1 & 26.3 & 35.9 & 28.4 \\
\hline instruments & 3,328 & 115 & 73.4 & 47.1 & 26.6 & 39.5 \\
\hline art work & 5,649 & 111 & 66.8 & 36.4 & 33.2 & 34.1 \\
\hline recycling & 2,555 & 113 & 85.1 & 71.3 & 14.9 & 77.4 \\
\hline all & 133,626 & 110 & 69.3 & 45.1 & 30.7 & 41.2 \\
\hline
\end{tabular}

Note: "Born \& rapid exporters" refer to firms that start exporting within 3 years of inception. "Slow exporters" refer to firms that start exporting after 3 years (but after no more than 6 years) of domestic operation. 
Table 3. Definition and descriptive analysis of main variables

\begin{tabular}{llrrrr}
\hline Name & Operationalization & Mean & s.d. & Min & Max \\
\hline Age & Current year - founding year & 3.772 & 2.104 & 0.000 & 10.000 \\
Size & Logarithm of total number of employees & 9.376 & 1.134 & 2.996 & 16.059 \\
Product diversity & Number of product lines, from 1 to 3 & 1.327 & 0.641 & 0.000 & 3.000 \\
Productivity & Logarithm of firm-level total factor productivity & 4.492 & 1.046 & -5.841 & 8.887 \\
Population density & Number of exporters in each industry & 258.9 & 443.7 & 0.000 & 2015 \\
Exporter competition & Export competition in each industry & 0.975 & 0.048 & 0.000 & 0.999 \\
Foreign ownership & Firm-level foreign capital share & 0.346 & 0.443 & 0.000 & 0.490 \\
Entry speed & 7 - no. of years between startup and initial exports & 4.382 & 1.643 & 1.000 & 7.000 \\
\hline
\end{tabular}

Table 4. Correlation coefficients

\begin{tabular}{|c|c|c|c|c|c|c|c|c|}
\hline & 1 & 2 & 3 & 4 & 5 & 6 & 7 & 8 \\
\hline 1. Age & 1.000 & & & & & & & \\
\hline 2. Size & 0.143 & 1.000 & & & & & & \\
\hline 3. Product diversity & 0.061 & 0.090 & 1.000 & & & & & \\
\hline 4. Productivity & 0.056 & 0.089 & -0.045 & 1.000 & & & & \\
\hline 5. Population density & 0.049 & -0.149 & -0.077 & 0.037 & 1.000 & & & \\
\hline 6. Exporter competition & 0.116 & -0.100 & -0.018 & 0.044 & 0.244 & 1.000 & & \\
\hline 7. Foreign ownership & -0.006 & 0.273 & 0.042 & -0.071 & -0.021 & -0.026 & 1.000 & \\
\hline 8. Entry speed & -0.052 & -0.044 & -0.050 & -0.018 & $-0.002^{+}$ & -0.073 & 0.065 & 1.000 \\
\hline
\end{tabular}

Note: all coefficients are significant at the $1 \%$ level, except for ${ }^{+}$(not significant)

Table 5. Estimating entry-speed strategy

\begin{tabular}{lll}
\hline Model & 1 & 2 \\
& $\begin{array}{l}\text { Coefficients } \\
\text { for full sample }\end{array}$ & $\begin{array}{l}\text { Coefficients } \\
\text { for split sample }\end{array}$ \\
\hline Size & $-0.143^{* * *}$ & $-0.138^{* * *}$ \\
& $(0.006)$ & $(0.008)$ \\
Productivity & $-0.038^{* * *}$ & $-0.040^{* * *}$ \\
Exporter competition & $(0.006)$ & $(0.009)$ \\
& $-2.955^{* * *}$ & $-2.803^{* * *}$ \\
Foreign ownership & $(0.120)$ & $(0.171)$ \\
& $0.310^{* * *}$ & $0.291 * * *$ \\
F value & $(0.016)$ & $(0.022)$ \\
\hline
\end{tabular}

Note: (1) $* * *$ represents significance at the $1 \%$ level. (2) Dummy variables for 30 provinces are included in the regressions, but are not reported here for brevity. 
Table 6. Estimating exit from export market (a full sample)

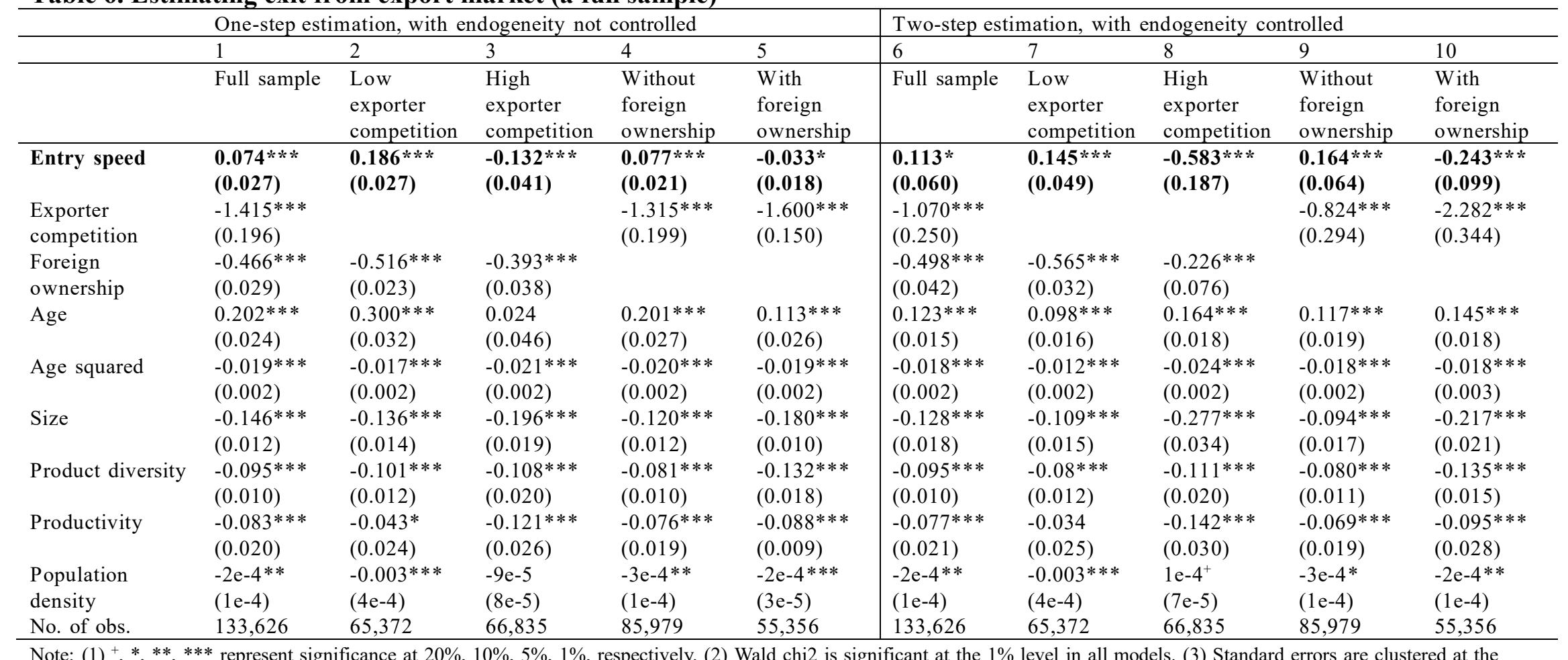

Note: $(1)^{+}, *, * * * * *$ represent significance at $20 \%, 10 \%, 5 \%, 1 \%$, respectively. (2) Wald chi2 is significant at the $1 \%$ level in all models. (3) Standard errors are clustered at the two-digit industry level and reported in parentheses. (4) Dummy variables for 30 provinces are included in the regressions, but are not reported here for brevity. (5) Coefficients may be interpreted as hazard ratios after transformation of exponential functions, e.g. a one-year increase in entry speed increases the hazard by $12.0 \%$ in Model 6 because $\exp (0.113)=1.120$. 
Table 7. A robustness test on sample dependence

\begin{tabular}{|c|c|c|c|c|c|c|}
\hline Model & 1 & 2 & 3 & 4 & 5 & 6 \\
\hline & Baseline & $\begin{array}{l}\text { Full } \\
\text { (fitted } \\
\text { speed) }\end{array}$ & $\begin{array}{l}\text { Low } \\
\text { exporter } \\
\text { competition }\end{array}$ & $\begin{array}{l}\text { High } \\
\text { exporter } \\
\text { competition }\end{array}$ & $\begin{array}{l}\text { Without } \\
\text { foreign } \\
\text { ownership }\end{array}$ & $\begin{array}{l}\text { With } \\
\text { foreign } \\
\text { ownership }\end{array}$ \\
\hline Entry speed & $\begin{array}{l}-0.017 \\
(0.025)\end{array}$ & $\begin{array}{l}0.259 \\
(0.433)\end{array}$ & $\begin{array}{l}0.134 * * \\
(0.070)\end{array}$ & $\begin{array}{l}-16.326 * * \\
(7.883)\end{array}$ & $\begin{array}{l}0.565^{+} \\
(0.368)\end{array}$ & $\begin{array}{l}-0.862 * * * \\
(0.206)\end{array}$ \\
\hline Exporter competition & $\begin{array}{l}-1.355^{* * *} \\
(0.209)\end{array}$ & $\begin{array}{l}-0.638 \\
(1.298)\end{array}$ & & & $\begin{array}{l}0.448 \\
(1.081)\end{array}$ & $\begin{array}{l}-4.241 * * * \\
(0.643)\end{array}$ \\
\hline Foreign ownership & $\begin{array}{l}-0.442 * * * \\
(0.026)\end{array}$ & $\begin{array}{l}-0.518 * * * \\
(0.127)\end{array}$ & $\begin{array}{l}-0.535^{* * *} \\
(0.035)\end{array}$ & $\begin{array}{l}4.368^{*} \\
(2.310)\end{array}$ & & \\
\hline Age & $\begin{array}{l}0.110 * * * \\
(0.024)\end{array}$ & $\begin{array}{l}0.128 * * * \\
(0.014)\end{array}$ & $\begin{array}{l}0.111 * * * \\
(0.016)\end{array}$ & $\begin{array}{l}0.158 * * * \\
(0.022)\end{array}$ & $\begin{array}{l}0.124 * * * \\
(0.020)\end{array}$ & $\begin{array}{l}0.143 * * * \\
(0.021)\end{array}$ \\
\hline Age squared & $\begin{array}{l}-0.020^{* * *} \\
(0.002)\end{array}$ & $\begin{array}{l}-0.020 * * * \\
(0.002)\end{array}$ & $\begin{array}{l}-0.015^{* * *} \\
(0.002)\end{array}$ & $\begin{array}{l}-0.024 * * * \\
(0.003)\end{array}$ & $\begin{array}{l}-0.020 * * * \\
(0.003)\end{array}$ & $\begin{array}{l}-0.019 * * * \\
(0.003)\end{array}$ \\
\hline Size & $\begin{array}{l}-0.149 * * * \\
(0.012)\end{array}$ & $\begin{array}{l}-0.114 * * \\
(0.058)\end{array}$ & $\begin{array}{l}-0.117 * * * \\
(0.015)\end{array}$ & $\begin{array}{l}-2.444 * * \\
(1.093)\end{array}$ & $\begin{array}{l}-0.049 \\
(0.051)\end{array}$ & $\begin{array}{l}-0.299 * * * \\
(0.025)\end{array}$ \\
\hline Product diversity & $\begin{array}{l}-0.084 * * * \\
(0.014)\end{array}$ & $\begin{array}{l}-0.084 * * * \\
(0.014)\end{array}$ & $\begin{array}{l}-0.088^{* * * *} \\
(0.016)\end{array}$ & $\begin{array}{l}-0.095 * * * \\
(0.025)\end{array}$ & $\begin{array}{l}-0.075^{* * *} \\
(0.015)\end{array}$ & $\begin{array}{l}-0.110 * * * \\
(0.021)\end{array}$ \\
\hline Productivity & $\begin{array}{l}-0.080 * * * \\
(0.020)\end{array}$ & $\begin{array}{l}-0.070^{* * *} \\
(0.025)\end{array}$ & $\begin{array}{l}-0.036^{+} \\
(0.024)\end{array}$ & $\begin{array}{l}-0.788 * * \\
(0.342)\end{array}$ & $\begin{array}{l}-0.052 * * * \\
(0.024)\end{array}$ & $\begin{array}{l}-0.123 * * * \\
(0.020)\end{array}$ \\
\hline Population density & $\begin{array}{l}-2 e-4 * \\
(1 e-4)\end{array}$ & $\begin{array}{l}-2 \mathrm{e}-4^{*} \\
(1 \mathrm{e}-4)\end{array}$ & $\begin{array}{l}-0.003 * * * \\
(0.001)\end{array}$ & $\begin{array}{l}-2 \mathrm{e}-4 * * * \\
(1 \mathrm{e}-5)\end{array}$ & $\begin{array}{l}-3 e-4 * * \\
(1 e-4)\end{array}$ & $\begin{array}{l}-1 \mathrm{e}-4 * \\
(1 \mathrm{e}-4)\end{array}$ \\
\hline No. of obs. & 66,738 & 66,738 & 33,085 & 33,652 & 38,612 & 28,125 \\
\hline
\end{tabular}

Note: $(1)^{+}, * * *, * * *$ represent significance at $20 \%, 10 \%, 5 \%, 1 \%$, respectively. (2) Wald chi2 is significant at the $1 \%$ level in all models. (3) Standard errors are clustered at the two-digit industry level and reported in parentheses. (4) Dummy variables for 30 provinces are included in the regressions, but are not reported here for brevity. (5) Coefficients may be interpreted as hazard ratios after transformation of exponential functions, e.g. a one-year increase in entry speed decreases the hazard by $57.8 \%$ in Model 6 because $\exp (-0.862)=0.422$. 
Table 8. A robustness test on technology intensity

\begin{tabular}{|c|c|c|c|c|c|c|c|c|c|c|}
\hline & \multicolumn{5}{|c|}{ High-technology industries } & \multicolumn{5}{|c|}{ Other industries } \\
\hline & 1 & 2 & 3 & 4 & 5 & 6 & 7 & 8 & 9 & 10 \\
\hline & $\begin{array}{l}\text { Full } \\
\text { model }\end{array}$ & $\begin{array}{l}\text { Low } \\
\text { exporter } \\
\text { competition }\end{array}$ & $\begin{array}{l}\text { High } \\
\text { exporter } \\
\text { competition }\end{array}$ & $\begin{array}{l}\text { Without } \\
\text { foreign } \\
\text { ownership }\end{array}$ & $\begin{array}{l}\text { With } \\
\text { foreign } \\
\text { ownership }\end{array}$ & $\begin{array}{l}\text { Full } \\
\text { model }\end{array}$ & $\begin{array}{l}\text { Low } \\
\text { exporter } \\
\text { competition }\end{array}$ & $\begin{array}{l}\text { High } \\
\text { exporter } \\
\text { competition }\end{array}$ & $\begin{array}{l}\text { Without } \\
\text { foreign } \\
\text { ownership }\end{array}$ & $\begin{array}{l}\text { With } \\
\text { foreign } \\
\text { ownership }\end{array}$ \\
\hline Entry speed & $\begin{array}{l}0.028 \\
(0.154)\end{array}$ & $\begin{array}{l}0.296 * * * \\
(0.120)\end{array}$ & $\begin{array}{l}-0.268 * * \\
(0.118)\end{array}$ & $\begin{array}{l}0.067 \\
(0.216)\end{array}$ & $\begin{array}{l}-0.173 * * * \\
(0.033)\end{array}$ & $\begin{array}{l}0.114 * \\
(0.067)\end{array}$ & $\begin{array}{l}0.113 * * \\
(0.055)\end{array}$ & $\begin{array}{l}-0.591 * * * \\
(0.197)\end{array}$ & $\begin{array}{l}0.170 * * \\
(0.070)\end{array}$ & $\begin{array}{l}-0.248 * * \\
(0.108)\end{array}$ \\
\hline Exporter competition & $\begin{array}{l}-1.572 * * * \\
(0.598)\end{array}$ & & & $\begin{array}{l}-0.989 \\
(0.849)\end{array}$ & $\begin{array}{l}-3.264 * * * \\
(0.519)\end{array}$ & $\begin{array}{l}-1.004 * * * \\
(0.261)\end{array}$ & & & $\begin{array}{l}-0.791 * * * \\
(0.311)\end{array}$ & $\begin{array}{l}-2.154 * * * \\
(0.375)\end{array}$ \\
\hline Foreign ownership & $\begin{array}{l}-0.488^{* * * *} \\
(0.124)\end{array}$ & $\begin{array}{l}-0.666^{* * *} \\
(0.115)\end{array}$ & $\begin{array}{l}-0.339 * * * \\
(0.062)\end{array}$ & & & $\begin{array}{l}-0.489 * * * \\
(0.046)\end{array}$ & $\begin{array}{l}-0.545^{* * *} \\
(0.037)\end{array}$ & $\begin{array}{l}-0.220 * * * \\
(0.080)\end{array}$ & & \\
\hline Age & $\begin{array}{l}0.082 * * * \\
(0.022)\end{array}$ & $\begin{array}{l}0.099 * * * \\
(0.037)\end{array}$ & $\begin{array}{l}0.070 * * * \\
(0.005)\end{array}$ & $\begin{array}{l}0.057^{*} \\
(0.032)\end{array}$ & $\begin{array}{l}0.119 * * * \\
(0.041)\end{array}$ & $\begin{array}{l}0.127 * * * \\
(0.016)\end{array}$ & $\begin{array}{l}0.100 * * * \\
(0.018)\end{array}$ & $\begin{array}{l}0.169 * * * \\
(0.018)\end{array}$ & $\begin{array}{l}0.121 * * * \\
(0.020)\end{array}$ & $\begin{array}{l}0.151 * * * \\
(0.020)\end{array}$ \\
\hline Age squared & $\begin{array}{l}-0.014 * * * \\
(0.002)\end{array}$ & $\begin{array}{l}-0.019 * * * \\
(0.004)\end{array}$ & $\begin{array}{l}-0.006^{* * * *} \\
(2 \mathrm{e}-4)\end{array}$ & $\begin{array}{l}-0.014 * * * \\
(0.005)\end{array}$ & $\begin{array}{l}-0.015^{* * * *} \\
(0.004)\end{array}$ & $\begin{array}{l}-0.018^{* * *} \\
(0.002)\end{array}$ & $\begin{array}{l}-0.011 * * * \\
(0.002)\end{array}$ & $\begin{array}{l}-0.024 * * * \\
(0.002)\end{array}$ & $\begin{array}{l}-0.018^{* * *} \\
(0.002)\end{array}$ & $\begin{array}{l}-0.019 * * * \\
(0.003)\end{array}$ \\
\hline Size & $\begin{array}{l}-0.119^{*} \\
(0.073)\end{array}$ & $\begin{array}{l}-0.072 \\
(0.081)\end{array}$ & $\begin{array}{l}-0.188^{* * * *} \\
(0.019)\end{array}$ & $\begin{array}{l}-0.094 \\
(0.088)\end{array}$ & $\begin{array}{l}-0.145^{* * * *} \\
(0.048)\end{array}$ & $\begin{array}{l}-0.125^{* * * *} \\
(0.018)\end{array}$ & $\begin{array}{l}-0.106^{* * *} \\
(0.015)\end{array}$ & $\begin{array}{l}-0.278 * * * \\
(0.036)\end{array}$ & $\begin{array}{l}-0.091^{* * *} \\
(0.016)\end{array}$ & $\begin{array}{l}-0.215 * * * \\
(0.021)\end{array}$ \\
\hline Product diversity & $\begin{array}{l}-0.083 * * * \\
(0.018)\end{array}$ & $\begin{array}{l}-0.087 * * * \\
(0.021)\end{array}$ & $\begin{array}{l}-0.003 \\
(0.036)\end{array}$ & $\begin{array}{l}-0.095^{* * *} \\
(0.034)\end{array}$ & $\begin{array}{l}-0.074 * * \\
(0.032)\end{array}$ & $\begin{array}{l}-0.096^{* * *} \\
(0.011)\end{array}$ & $\begin{array}{l}-0.095^{* * *} \\
(0.014)\end{array}$ & $\begin{array}{l}-0.116^{* * *} \\
(0.020)\end{array}$ & $\begin{array}{l}-0.079 * * * \\
(0.011)\end{array}$ & $\begin{array}{l}-0.141 * * * \\
(0.016)\end{array}$ \\
\hline Productivity & $\begin{array}{l}-0.034 \\
(0.023)\end{array}$ & $\begin{array}{l}0.008 \\
(0.035)\end{array}$ & $\begin{array}{l}-0.061^{+} \\
(0.047)\end{array}$ & $\begin{array}{l}-0.038 \\
(0.038)\end{array}$ & $\begin{array}{l}-0.044 * * * \\
(0.016)\end{array}$ & $\begin{array}{l}-0.100 * * * \\
(0.017)\end{array}$ & $\begin{array}{l}-0.064 * * * \\
(0.011)\end{array}$ & $\begin{array}{l}-0.154 * * * \\
(0.036)\end{array}$ & $\begin{array}{l}-0.084 * * * \\
(0.018)\end{array}$ & $\begin{array}{l}-0.137 * * * \\
(0.016)\end{array}$ \\
\hline Population density & $\begin{array}{l}-0.001 * * * \\
(3 e-4)\end{array}$ & $\begin{array}{l}-0.008^{*} \\
(0.005)\end{array}$ & $\begin{array}{l}-0.003^{* * *} \\
(5 e-4)\end{array}$ & $\begin{array}{l}-0.002 * * * \\
(0.001)\end{array}$ & $\begin{array}{l}-0.001 * * * \\
(1 \mathrm{e}-4)\end{array}$ & $\begin{array}{l}-2 e-4 * * \\
(1 e-4)\end{array}$ & $\begin{array}{l}-0.003^{* * *} \\
(5 e-4)\end{array}$ & $\begin{array}{l}-1 \mathrm{e}-4^{+} \\
(1 \mathrm{e}-4)\end{array}$ & $\begin{array}{l}-3 e-4 * * \\
(1 e-4)\end{array}$ & $\begin{array}{l}-2 \mathrm{e}-4 * * \\
(1 \mathrm{e}-4)\end{array}$ \\
\hline No. of obs. & 8,890 & 6,669 & 2,220 & 3,697 & 5,193 & 123,237 & 62,894 & 60,343 & 68,762 & 54,475 \\
\hline
\end{tabular}

Note: $(1)^{+}, *, * *, * * *$ represent significance at $20 \%, 10 \%, 5 \%, 1 \%$, respectively. (2) Wald chi2 is significant at the $1 \%$ level in all models. (3) Standard errors are clustered at the two-digit industry level and reported in parentheses. (4) Some firms do not report their industry affiliation, causing a loss of $1 \%$ observations. (5) Dummy variables for 30

provinces are included in the regressions, but are not reported here for brevity. (5) Coefficients may be interpreted as hazard ratios after transformation of exponential functions, e.g. a one-year increase in entry speed decreases the hazard by $23.5 \%$ in Model 3 because $\exp (-0.268)=0.765$. 


\begin{tabular}{llr}
\multicolumn{2}{l}{ Appendix 1. Sample screening process } & \\
\hline Step \# & Data contraction and extension & No. of obs. \\
\hline 1 & Include all observations from the original database & $2,638,016$ \\
2 & Exclude firms with more than 250 employees & $2,042,342$ \\
3 & Exclude firms founded before 1998 & $1,106,131$ \\
4 & Exclude firms with more than $50 \%$ foreign ownership share & 929,175 \\
5 & Exclude state-owned enterprises & 906,626 \\
6 & Exclude firms that never export & 164,034 \\
7 & Exclude exporters that start exporting after six years of inception & 96,568 \\
8 & Extend one year for every firm in order to conduct the Cox model & 145,284 \\
9 & Exclude observations without values of explanatory variables & 133,626 \\
\hline
\end{tabular}

